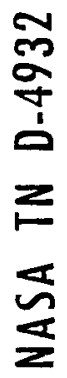

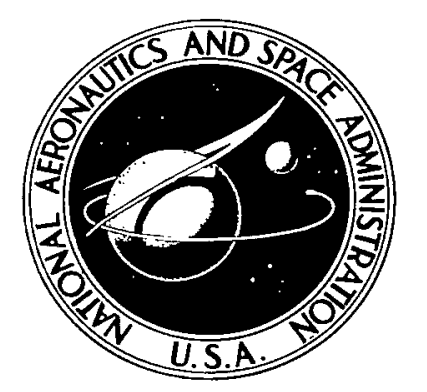

$\frac{\text { NASA IN } 0.4932}{C .1}$

LOAN COPY: RETUF

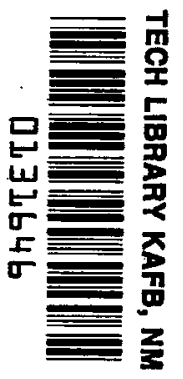

AFWL (WLIL-2)

KIRTLAND AFB, N MEX

\title{
ELASTIC SCATTERING OF
}

21-MeV PROTONS FROM NITROGEN 14,

OXYGEN 16, ARGON 40, NICKEL 58, AND TIN 116

by

Norton Baron and Regis F. Leonard

Lewis Research Center

and

David A. Lind

University of Colorado

national aeronautics and SpaCe administration - washington, D. C. - DeCember 1968 
ELASTIC SCATTERING OF 21-MeV PROTONS FROM NITROGEN 14, OXYGEN 16, ARGON 40, NICKEL 58, AND TIN 116

By Norton Baron and Regis F. Leonard

Lewis Research Center

Cleveland, Ohio

and

David A. Lind

University of Colorado

Boulder, Colorado 


\section{ABSTRACT}

Differential cross-section angular distributions were measured for $21-\mathrm{MeV}$ incident protons elastically scattered from ${ }^{14} \mathrm{~N},{ }^{16} \mathrm{O},{ }^{40} \mathrm{~A},{ }^{58} \mathrm{Ni}$, and ${ }^{116} \mathrm{Sn}$. An optical-model analysis was performed on these data and on previously measured elastic polarizations of $21-\mathrm{MeV}$ incident protons scattered from the same nuclei. The optical potential used in this analysis included a real central term, a surface absorption term, and a real spin-orbit term. Good fits to both the cross sections and polarizations for all nuclei except ${ }^{16} \mathrm{O}$ were obtained by allowing the nine parameters of the optical potential to vary from nucleus to nucleus. 


\title{
ELASTIC SCATTERING OF 21-MeV PROTONS FROM NITROGEN 14, OXYGEN 16, ARGON 40, NICKEL 58, AND TIN 116
}

\author{
by Norton Baron, Regis F. Leonard, and David A. Lind*
}

\author{
Lewis Research Center
}

\section{SUMMARY}

Differential cross-section angular distributions were measured for $21-\mathrm{MeV}$ incident protons elastically scattered from nitrogen $14\left({ }^{14} \mathrm{~N}\right)$, oxygen $16\left({ }^{16} \mathrm{O}\right)$, argon $40\left({ }^{40} \mathrm{~A}\right)$, nickel $58\left({ }^{58} \mathrm{Ni}\right)$, and tin $116\left({ }^{116} \mathrm{Sn}\right)$. An optical-model analysis was performed on these data and on previously measured elastic polarizations of $21-\mathrm{MeV}$ incident protons scattered from the same nuclei. The optical potential used in this analysis included a real central term, a surface absorption term, and a real spin-orbit term. Good fits to both the cross sections and polarizations for all nuclei except ${ }^{16} \mathrm{O}$ were obtained by allowing the nine parameters of the optical potential to vary from nucleus to nucleus. The diffuseness parameters derived to fit the ${ }^{14} \mathrm{~N}$ and ${ }^{16} \mathrm{O}$ data, in general, differed considerably from those derived to fit the scattering from the heavier nuclei. These results were compared with those of two other calculations in which two different sets of nonunique constant-geometric optical-model parameters were assumed, and only the three potential strengths were obtained by searching. As expected, these constant-geometry calculations gave poorer agreement with the data. The disagreement with the polarizations of ${ }^{14} \mathrm{~N}$ and ${ }^{16} \mathrm{O}$ was pronounced.

\section{INTRODUCTION}

The optical model can reproduce rather well the experimentally measured cross sections and polarizations, provided that the parameters in the optical-model potential are allowed to vary as a function of energy and nucleus (ref. 1). Considerable efforts are being made to find a universal optical-model potential or at least to establish trends in the parameters of the potential with changes in incident proton energy, atomic number, and/or mass number (refs. 2 to 8 ). In evolving such a potential, data are more useful if they include both cross sections and polarizations measured at the same incident proton energy. Consequently, in this report elastic cross sections for $21-\mathrm{MeV}$ incident protons

*Professor of Physics, University of Colorado, Boulder, Colorado. 
were measured for five nuclei which differ considerably in mass, and for which elastic polarizations at $21 \mathrm{MeV}$ were measured previously (ref. 9). For each nucleus, an optical model potential was determined which gave the "best fit" to both the cross-section and polarization data.

\section{EXPERIMENTAL ARRANGEMENT}

\section{General}

The differential cross-section angular distributions of protons elastically scattered from ${ }^{14} \mathrm{~N},{ }^{16} \mathrm{O},{ }^{40} \mathrm{~A},{ }^{58} \mathrm{Ni}$, and ${ }^{116} \mathrm{Sn}$ were measured by the use of a $21-\mathrm{MeV}$ proton beam extracted from the four-sector, fixed-frequency, alternating-gradient cyclotron at the University of Colorado. After being extracted by electrostatic deflection, the external beam is passed through a $10^{\circ}$ steering magnet and two quadrupole lenses, which provide separately for horizontal and vertical focusing. The beam then undergoes a deflection of $30^{\circ}$ through a switching magnet and passes into a 91.5-centimeter-diameter scattering chamber through a series of collimators that, in combination with the switching magnet, provide a degree of energy analysis. The detector was mounted on a remotely controlled, motor-driven tray. Similarly, targets were mounted on a remotely controlled, motor-driven table. The detector and target angles were known to $\pm 0.05^{\circ}$ with respect to the chamber coordinates.

\section{Particle Detection}

Reaction product particles were detected by windowless lithium-arifted siliconsemiconductor counters with a compensated depth of 4300 micrometers. These counters, fabricated at the NASA Lewis Research Center (ref. 10), were operated at a temperature of $208 \mathrm{~K}$ and at a bias of 400 volts with a leakage current of about 20 nanoamperes. The resolution of these counters, measured with a monoenergetic source of $8.78-\mathrm{MeV}$ alpha particles from polonium $212\left({ }^{212} \mathrm{Po}\right)$ is typically about $20 \mathrm{keV}$.

\section{Electronics}

The pulse from the detector was fed into a low-noise charge-sensitive preamplifier that was followed by a pulse shaper and further voltage amplification. The amplified pulses were then put into a 4096-channel pulse-height analyzer. The integrated beam 
passing through the target was collected in a Faraday cup of conventional design. The total charge collected in the Faraday cup was measured with a low-impedance voltage-tofrequency converter. Its output pulses were stored in the clock channel of the analyzer to give an automatic live-time correction. The spectrum and live-time charge were stored in 256-channel subgroups of the pulse-height analyzer and were dumped, after the accumulation of $\mathbf{1 6}$ spectra, onto magnetic tape for subsequent off-line printout.

\section{Beam Energy}

The incident beam energy was determined by a kinematic null method (refs. 11 and 12) using the angular dependence of energy for protons scattered from the first excited

state of carbon $12\left({ }^{12} \mathrm{C}\right)$ and from hydrogen. This determination of energy is considered to be accurate to $\pm 40 \mathrm{keV}$. The use of the null method on both the left and right sides of the target also determined the incident beam direction to $\pm 0.05^{\circ}$.

\section{Gas Target}

The nitrogen, oxygen, and argon gas targets consisted of an 8.5-centimeter-diameter disk-shaped cell with 6.35-micrometer-thick aluminized polyester-film side windows for the scattered protons and 12.5-micrometer-cobalt-nickel-chromium-alloy windows for the beam entrance and exit. The gas target was designed and constructed at the University of Colorado. The detector telescope consisted of two vertical slits, placed 10 inches $(25.4 \mathrm{~cm})$ apart, which defined the target volume and the solid angle. Cross sections were calculated by using only the first-order term in the expression derived by Silverstein (ref. 13).

\section{Energy Resolution}

Since the elastically scattered group was well separated from the inelastic groups, there was no need to optimize the resolution. Consequently, a reduction in data-taking time involved widening the incident beam collimating slits to increase the incident beam current. The pulse-height-analyzer resolution was coarse and of the order of $80 \mathrm{keV}$ per channel. The overall energy resolution was approximately $150 \mathrm{keV}$ (full width half maximum). 


\section{Cross Sections}

Relative cross sections. - Normally enough counts were accumulated in each spectrum so that the standard deviation was less than \pm 3 percent. The relative cross sections were always reproducible to within the statistical errors.

Absolute cross sections. - The major sources of probable error in the established scales of absolute cross sections are associated with (1) the determination of the target thickness and (2) the determination of the actual number of incident protons for a given amount of measured charge collection by the Faraday cup.

(1) The accurate determination of the gas target thickness depends primarily on the measurement of the gas pressure. The gas pressure in the target cell was approximately 1 atmosphere and was monitored with an accuracy of \pm 0.2 percent. The foil target thickness was determined by accurately weighing a known area of the foil target.

(2) The amount of the $21-\mathrm{MeV}$ incident proton beam that was deflected away from the Faraday cup by multiple scattering in the Havar gas cell windows was estimated to be negligible. Uncertainties in the integrated incident flux were estimated to be less than 1 percent.

When other effects, such as detector efficiency and solid-angle measurement were included, the overall uncertainty in the absolute cross sections was estimated to be less than 5 percent for all the angular distribution measurements reported in this experiment.

\section{EXPERIMENTAL CROSS SECTIONS AND THEIR STATISTICAL ERRORS}

Cross sections were obtained for elastic scattering $\left(5^{\circ}<\theta_{\text {lab }}<170^{\circ}\right)$ of $21-\mathrm{MeV}$ incident protons by gas targets of ${ }^{14} \mathrm{~N},{ }^{16} \mathrm{O}$, and ${ }^{40} \mathrm{~A}$ and by foil targets of ${ }^{58} \mathrm{Ni}$ and ${ }^{116} \mathrm{Sn}$.

The experimental differential cross sections (in $\mathrm{mb} / \mathrm{sr}$ ) and their associated statistical counting errors (in $\mathrm{mb} / \mathrm{sr}$ ) are listed in the tables on pages 11 to 18 for scattering by ${ }^{14} \mathrm{~N},{ }^{16} \mathrm{O},{ }^{40} \mathrm{~A},{ }^{58} \mathrm{Ni}$, and ${ }^{116} \mathrm{Sn}$. The measured elastic polarizations (ref. 9) are also listed there. These angular distributions, plotted as the ratio to Rutherford scattering, are presented in figures $1(\mathrm{a}), 2(\mathrm{a}), 3(\mathrm{a}), 4(\mathrm{a})$, and 5(a), respectively.

\section{THE OPTICAL-MODEL POTENTIAL}

The optical potential used for the analysis of these scattering data can be written as 


$$
\begin{aligned}
U(r)=V_{c}(r)-V f\left(r, r_{0}, a_{0}\right)+4 i W a_{i} \frac{d}{d r} & {\left[f\left(r, r_{i}, a_{i}\right)\right] } \\
& +\left(\frac{h}{2 \pi m_{p} c}\right)^{2} V_{\text {so }} \frac{1}{r} \frac{d}{d r}\left[f\left(r, r_{s o}, a_{s o}\right)\right] \vec{\imath} \cdot \vec{\sigma}
\end{aligned}
$$

where $V_{c}(r)$ is the Coulomb potential between the incident proton and the scattering nucleus, which is assumed to be a uniformly charged sphere of radius

$$
R_{c}=r_{c} A^{1 / 3}
$$

and has the form

$$
\begin{gathered}
V_{c}(r)=\frac{z e^{2}}{2 r}\left[3-\left(\frac{r}{R_{c}}\right)^{2}\right] \quad r \leq R_{c} \\
V_{c}(r)=\frac{z e^{2}}{r} \quad r \geq R_{c}
\end{gathered}
$$

and $\mathrm{V}$ and $\mathrm{W}$ are the strengths of the real and imaginary parts of the complex central potential and account for the nuclear scattering and absorption, respectively, by the central potential; $f(r)$ denotes the Woods-Saxon radial form factor and has the form

$$
f(r)=\left[1+\exp \left(\frac{r-r_{x} A^{1 / 3}}{a_{x}}\right)\right]^{-1}
$$

which is constant in the nuclear interior, falls off in the surface region, and finally drops exponentially to zero. Consequently, the radial derivative of this form factor reaches a maximum in the surface region and makes the imaginary part of the central potential essentially a surface absorption term. In this expression, $r_{x} A^{1 / 3}$ measures the overall extent of the potential and is thus a measure of the nuclear radius. The parameter $a_{x}$ controls the rapidity with which $f(r)$ falls from its maximum value; it is therefore related to the diffuseness of the nuclear surface.

The remaining term in equation (1) is the spin-orbit potential term which is taken proportional to $\vec{l} \cdot \vec{\sigma}$, where $\vec{l}$ and $\vec{\sigma}$ are the angular momentum and Pauli spin, 
respectively. For bound particles of negative energy, this spin-dependent term successfully gives the sequence of nuclear states in the shell model. As symmetry requires the spin-orbit forces to be zero in the nuclear interior, the spin-dependent potential may be expected to be small inside the nucleus and appreciable only in the surface region. Consequently, the Thomas form was assumed with the derivative of the Woods-Saxon radial form factor, which has the required surface peaking and a spin-orbit potential strength given by $\mathrm{V}_{\text {so }}$.

Volume absorption was not used in this analysis, in accordance with the results of a recent analysis of $18.6-\mathrm{MeV}$ proton cross-section and polarization data (ref. 8).

\section{OPTICAL MODEL ANALYSES OF ${ }^{14} \mathrm{~N},{ }^{16} 0,{ }^{40} \mathrm{~A},{ }^{58} \mathrm{Ni}$, AND ${ }^{116} \mathrm{Sn}$}

For each of the several nuclei studied, an optical-model analysis was performed to fit simultaneously the polarization and elastic angular distributions. The calculations were performed with an optical-model computer program. The automatic search provision of this program was written by Davidon (ref. 14) and was adapted for use at this Center (unpublished work by Volkin and Giamati of Lewis). The program varies the nine independent parameters of the optical potential to minimize the quantity $x^{2} / N$, which is defined as

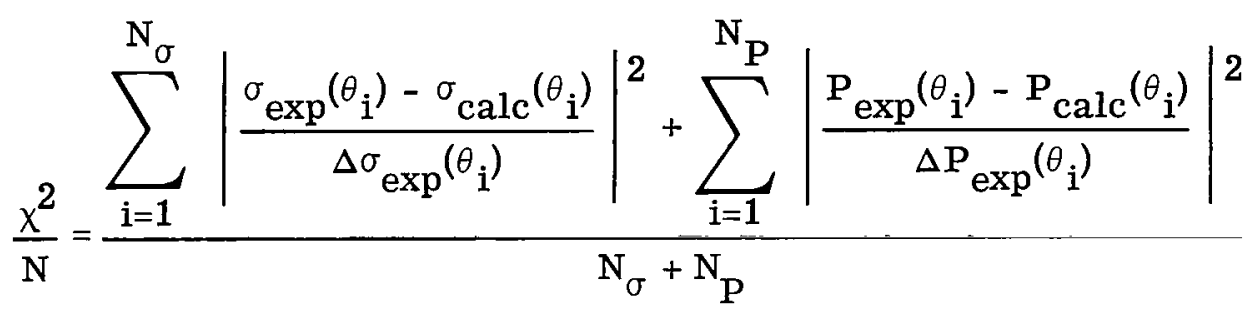

where

$\mathbf{N}_{\sigma}$

$\sigma_{\exp }\left(\theta_{i}\right)$

$\sigma_{\text {calc }}{ }^{\left(\theta_{i}\right)}$

$\Delta \sigma_{\exp }\left(\theta_{\mathbf{i}}\right)$

$\mathrm{N}_{\mathbf{P}}$

$P_{\exp }\left(\theta_{i}\right)$ number of experimental data points for cross sections experimentally measured differential cross sections at angle $\theta_{i}$ calculated differential cross sections experimental uncertainty associated with measured differential cross sections

number of experimental data points for polarizations experimentally measured differential polarizations at angle $\theta_{\mathbf{i}}$ 
$\mathbf{P}_{\text {calc }}\left(\theta_{\mathbf{i}}\right) \quad$ calculated differential polarizations

$\Delta \mathbf{P}_{\exp }\left(\theta_{\mathbf{i}}\right)$ experimental uncertainty associated with measured differential polarizations

The experimental uncertainties of the cross sections were set equal to 10 percent of the measured cross sections to give a uniform weight to each data point.

A series of calculations was performed for each isotope, whereby the three potential strengths $\left(\mathrm{V}, \mathrm{w}\right.$, and $\left.\mathrm{v}_{\mathrm{so}}\right)$ and the three diffusenesses $\left(\mathrm{a}_{0}, \mathrm{a}_{\mathrm{i}}\right.$, and $\left.\mathrm{a}_{\text {so }}\right)$ were obtained by a six-parameter search. The three radii $\left(r_{0}, r_{i}\right.$, and $\left.r_{\text {so }}\right)$, although fixed during each calculation, were varied independently in successive calculations in steps of 0.03 fermi within the limits

$$
\begin{aligned}
& 1.16 \leq \mathrm{r}_{0} \leq 1.25 \mathrm{~F} \\
& 1.16 \leq \mathrm{r}_{\mathrm{i}} \leq 1.25 \mathrm{~F} \\
& 0.99 \leq \mathrm{r}_{\mathrm{SO}} \leq 1.14 \mathrm{~F}
\end{aligned}
$$

The parametric values that gave the best fit to the experimental data were then used as starting values for a nine-parameter search calculation. The results of these calculations are listed in table $I$ and are shown in figures 1 to 5 . Quoted in table I are the quantities $x^{2} / N$, defined by equation (2), and $x_{\sigma}^{2} / N_{\sigma}$ and $x_{\mathrm{p}}^{2} / \mathrm{N}_{\mathrm{p}}$, defined by

$$
\frac{x_{\sigma}^{2}}{\mathbf{N}_{\sigma}}=\frac{\sum_{\mathbf{i}=1}^{\mathrm{N}_{\sigma}}\left|\frac{\sigma_{\exp }\left(\theta_{\mathbf{i}}\right)-\sigma_{\text {calc }}\left(\theta_{\mathbf{i}}\right)}{\Delta \sigma_{\exp }\left(\theta_{\mathbf{i}}\right)}\right|^{2}}{\mathbf{N}_{\sigma}}
$$

and

$$
\frac{\chi_{p}^{2}}{N_{P}}=\frac{\sum_{i=1}^{N_{p}}\left|\frac{P_{\exp ^{\left(\theta_{i}\right)}-P_{c a l c}\left(\theta_{i}\right)}}{\Delta P_{\exp ^{\left(\theta_{i}\right)}}}\right|^{2}}{N_{P}}
$$


Guided by the results listed in table I, a number of three-parameter search calculations were performed to determine how well the scattering from these nuclei could be described by using fixed values for all the radii and diffusenesses. The results of one such set of calculations, somewhat typical, are listed in table $\Pi$ and shown in figures 1 to 5 for comparison with the results of the nine-parameter search calculations. Reasonable fits were obtained for all the data except the polarizations of ${ }^{14} \mathrm{~N}$ and ${ }^{16} \mathrm{O}$. Since only five nuclei were studied, there is no intent herein to propose that these particular values of the geometric quantities represent a unique set of average optical-model potential parameters for 21-MeV protons.

For reference, in another series of calculations, the three potential strengths were determined by searching, using the fixed geometry suggested by Perey (ref. 2). The results of these calculations are listed in table $\mathrm{II}$ and shown in figures 1 to 5 .

\section{DISCUSSION AND CONCLUSIONS}

It is only useful to comment on calculations of the differential cross sections and polarizations, because there are no reported measured values of the reaction cross sections for $21-\mathrm{MeV}$ protons for these nuclei. Also, because only five nuclei were studied herein, no statement can be made concerning the dependence of the optical-model potential on an isobaric spin term. The cross sections and polarizations for $21-\mathrm{MeV}$ protons incident on ${ }^{40} \mathrm{~A},{ }^{58} \mathrm{Ni}$, and ${ }^{116} \mathrm{Sn}$ are well described by a nine-parameter search. The starting values were obtained by previously gridding on the three radii and searching in a six-parameter space of the three potential strengths and diffusenesses. The resultant radii do not differ greatly among these nuclei. Typically, the spin-orbit radius is about 16 percent less than the radius of the real central potential term and is about 25 percent less than the radius of the absorptive potential term. The spin-orbit diffuseness tends to decrease for heavier nuclei, whereas the diffuseness of the real central potential term is relatively constant and is about 0.72 fermi.

The constant geometric parameters suggested by Perey (ref. 2) were determined by an optical-model analysis of 35 different proton angular distributions at five different incident proton energies ranging from 9.4 to $22.2 \mathrm{MeV}$. The general characteristics of both the polarizations and cross sections are reproduced for each of the three nuclei. However, the values of $x^{2} / \mathrm{N}$ may be reduced by a factor of 2 to 10 by using a potential derived to fit only the data presented herein, as illustrated in tables $I I$ and III.

The optical model is expected to be more successful for heavy- and medium-weight nuclei than for light nuclei, as they more nearly approach the limit of uniform nuclear matter with few isolated resonances to affect the interaction. For lighter nuclei, fluctuations in the parameters are expected to be larger due to differences in nuclear struc- 
ture and the smaller density of levels in the compound system. This problem was previously investigated by Daehnick (ref. 15), who analyzed the scattering of 13- to $19-\mathrm{MeV}$ protons by ${ }^{16} \mathrm{O}$. He observed that the interference of potential scattering with compound nuclear scattering is strong for even $200-\mathrm{keV}$ resolution. Consequently, the application of the optical model to nuclei as light as ${ }^{14} \mathrm{~N}$ and ${ }^{16} \mathrm{O}$ is questionable and is illustrated by the results of a nine-parameter search calculation on ${ }^{14} \mathrm{~N}$ and ${ }^{16} \mathrm{O}$. For ${ }^{14} \mathrm{~N}$, the parameters obtained from such a claculation gave a good overall fit, but, in general, the diffuseness parameters differed considerably from those obtained for ${ }^{40} \mathrm{~A},{ }^{58} \mathrm{Ni}$, and ${ }^{116} \mathrm{Sn}$. The constant geometric parameters listed in tables II and III each give good fits to the ${ }^{14} \mathrm{~N}$ cross sections, but the polarization fits are poor. Similarly, for ${ }^{16} \mathrm{O}$ the constant geometric parameters listed in tables $\mathrm{II}$ and $\mathrm{II}$ result in a poor agreement with the polarization data. However, the quality of fit to these data is considerably improved by the unrestricted nine-parameter-search optical-model calculation.

Lewis Research Center,

National Aeronautics and Space Administration, Cleveland, Ohio, September 4, 1968, 129-02-04-06-22.

\section{REFERENCES}

1. Feshbach; Herman: The Optical Model and Its Justification. Annual Review of Nuclear Science. Vol. 8. Annual Reviews, Inc., 1958, pp. 49-104.

2. Perey, F. G.: Optical-Model Analysis of Proton Elastic Scattering in the Range of 9 to $22 \mathrm{MeV}$. Phys. Rev., vol. 131, no. 2, July 15, 1963, pp. 745-763.

3. Rosen, Louis; Beery, Jerome G.; Goldhaber, Alfred S. ; and Auerbach, Elliot H.: Elastic Scattering of 10.5- and 14.5-MeV Polarized Protons from Nuclei and the Optical Model Potential at Intermediate Energies. Ann. Phys. (N.Y.), vol. 34, no. 1, Aug. 1965, pp. 96-152.

4. Satchler, G. R.: Optical Model for $30 \mathrm{MeV}$ Proton Scattering. Nucl. Phys., vol. A92, 1967, pp. 273-305.

5. Picard, J.: Analyse de la Diffusion Nucléaire À Basse Énergie Par Le Modèle Optique. Nucl. Phys., vol. 68, 1965, pp. 153-160.

6. Baugh, D. J. ; Greenlees, G. W.; Lilley, J. S. ; and Roman, S.: Polarization of 17. $8 \mathrm{MeV}$ Protons Scattered by Nuclei. Nucl. Phys., vol. 65, 1965, pp. 33-42. 
7. Barrett, R. C.; Hill, A. D. ; and Hodgson, P. E.: Optical Model Studies of Proton Scattering at $30 \mathrm{MeV}$. (IV). Analysis. Nucl. Phys., vol. 62, 1965, pp. 133-144.

8. Kossanyi-Demay, P.; deSwiniarski, R.; and Glashausser, C.: An Optical-Model Analysis of 18.6 MeV Proton Elastic Scattering. Nucl. Phys., vol. A94, 1967, pp. 513-527.

9. Bercaw, R. W.; Boschitz, E. T.; and Vincent, J. S.: Elastic Scattering of 21-MeV Polarized Protons by Complex Nuclei. Proceedings of the $2^{\text {nd }}$ International Symposium on Polarization Phenomena of Nucleons. P. Huber and H: Schopper, eds., Berkhaeuser Verlag, 1966, pp. 334-335.

10. Baron, Norton; and Kaminski, Gerald A.: Manufacture of Lithium-Drifted Silicon Surface - Barrier Semiconductor Counters. NASA TN D-3554, 1966.

11. Bardin, B. M. ; and Rickey, M. E.: Kinematic Method for Determination of Accelerator Beam Energies. Rev. Sci. Instr., vol. 35, no. 7, July 1964, pp. 902-903.

12. Smythe, Rodman: Relativistic Equations and Tables for Ion Energy Determination by the Crossover Technique. Rev. Sci. Instr., vol. 35, no. 9, Sept. 1964, pp. 1197-1200.

13. Silverstein, Edward A.: Calculation of the G Factor for Gas Scattering Experiments. Nucl. Instr. Methods, vol. 4, 1959, pp. 53-66.

14. Davidon, William C.: Variable Metric Method for Minimization. Rep. ANL-5990, Argonne National Lab., Nov. 1959.

15. Daehnick, W. W.: Elastic and Inelastic Scattering of 13- to 19-MeV Protons by $\mathrm{O}^{16}$. Phys. Rev., vol. 135, no. 5B, Sept. 7, 1964, pp. 1168-1179. 
TABLE I. - RESULTS OF NINE-PARAMETER SEARCH

\begin{tabular}{|c|c|c|c|c|c|}
\hline & & & Target & & \\
\hline & ${ }^{14} \mathrm{~N}$ & ${ }^{16} \mathrm{O}$ & ${ }^{40} \mathrm{~A}$ & ${ }^{58} 8_{\mathrm{Ni}}$ & ${ }^{116}{ }_{\mathrm{Sn}}$ \\
\hline $\begin{array}{l}\text { Strength of real part of nuclear } \\
\text { optical potential, } \mathrm{V}, \mathrm{MeV}\end{array}$ & 53.3 & 50.5 & 50.6 & 52.2 & 53.9 \\
\hline $\begin{array}{l}\text { Diffuseness of real part of } \\
\text { nuclear optical potential, } \\
a_{0}, F\end{array}$ & 0.64 & 0.54 & 0.717 & 0.770 & 0.71 \\
\hline $\begin{array}{l}\text { Radius constant of real part of } \\
\text { nuclear optical potential, } \\
r_{0}, F\end{array}$ & 1.11 & 1.19 & 1.17 & 1.15 & 1.18 \\
\hline $\begin{array}{l}\text { Strength of imaginary part of } \\
\text { nuclear optical potential, } \\
\text { W, MeV }\end{array}$ & 7.14 & 9.14 & 8.25 & 8.87 & 10.6 \\
\hline $\begin{array}{l}\text { Diffuseness of imaginary part } \\
\text { of nuclear optical potential, } \\
a_{i}, F\end{array}$ & 0.36 & 0.36 & 0.676 & 0.517 & 0.660 \\
\hline $\begin{array}{l}\text { Radius constant of imaginary } \\
\text { part of nuclear optical } \\
\text { potential, } r_{i}, F\end{array}$ & 1.40 & 1.20 & 1.22 & 1.33 & 1.26 \\
\hline $\begin{array}{l}\text { Strength of spin-orbit potential, } \\
\quad \mathrm{V}_{\text {so }}, \mathrm{MeV}\end{array}$ & 5.68 & 2.75 & 5.64 & 4.93 & 5.24 \\
\hline $\begin{array}{l}\text { Diffuseness of spin-orbit } \\
\text { potential, } \mathrm{a}_{\text {so }}, \mathrm{F}\end{array}$ & 0.34 & 0.010 & 0.657 & 0.535 & 0.448 \\
\hline $\begin{array}{l}\text { Radius constant of spin-orbit } \\
\text { potential, } \mathrm{r}_{\text {so }}, \mathbf{F}\end{array}$ & 0.983 & 0.993 & 1.01 & 1.01 & 1.07 \\
\hline $\begin{array}{l}\text { Goodness of fit per data point, } \\
\chi^{2} / \mathrm{N}\end{array}$ & 2.08 & 13.95 & 3.83 & 1.93 & 0.705 \\
\hline $\begin{array}{l}\text { Goodness of fit per cross- } \\
\text { section data point, } x_{\sigma}^{2} / N_{P}\end{array}$ & 1.76 & 3.75 & 3.26 & 1.38 & 0.6 \\
\hline $\begin{array}{l}\text { Goodness of fit per polarization } \\
\text { data point, } x_{p}^{2} / N_{P}\end{array}$ & 2.83 & 34.4 & 5.26 & 2.81 & 0.905 \\
\hline Reaction cross section, $\sigma_{\mathbf{R}}, \mathrm{mb}$ & 480 & 490 & 1062 & 1093 & 1423 \\
\hline
\end{tabular}


TABLE II. - RESULTS OF SEARCH ON POTENTIAL STRENGTHS

$$
\begin{gathered}
\left(\mathrm{V}, \mathrm{W}, \text { AND } \mathrm{V}_{\text {SO }}\right) \text { USING SET OF NONUNIQUE } \\
\text { FIXED GEOMETRIC PARAMETERS }
\end{gathered}
$$

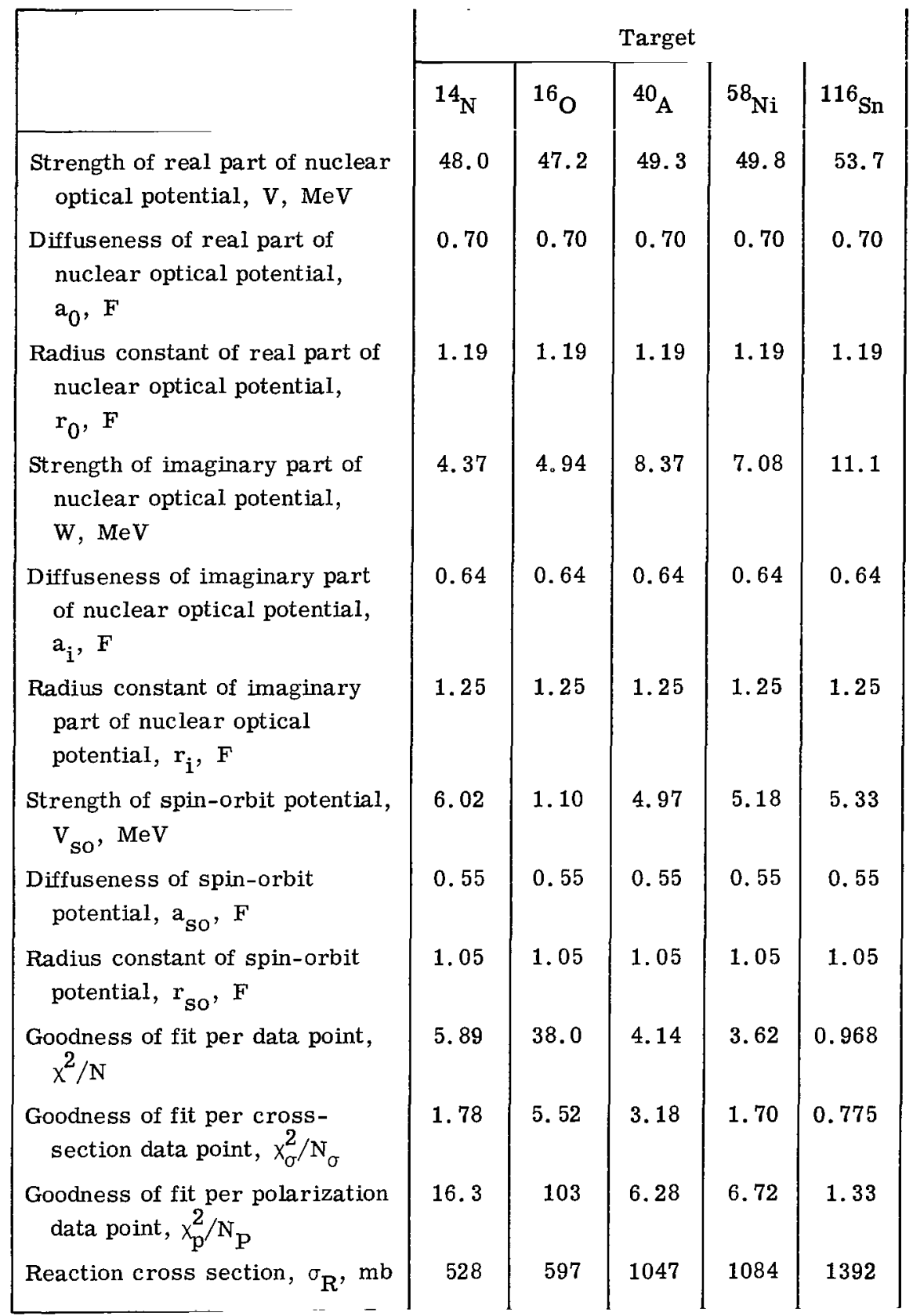


TABLE III. - RESULTS OF SEARCH ON POTENTIAL STRENGTHS

$\left(\mathrm{V}, \mathrm{W}\right.$, AND $\left.\mathrm{v}_{\mathrm{SO}}\right)$ USING SET OF FIXED GEOMETRIC

PARAMETERS SUGGESTED BY PEREY ${ }^{\mathrm{a}}$

\begin{tabular}{|c|c|c|c|c|c|}
\hline & & & Target & & \\
\hline & ${ }^{14} 4_{\mathrm{N}}$ & ${ }^{16} \mathrm{O}$ & ${ }^{40} \mathrm{~A}$ & ${ }^{58} \mathrm{Ni}$ & ${ }^{116}{ }_{\mathrm{Sn}}$ \\
\hline $\begin{array}{l}\text { Strength of real part of nuclear } \\
\text { optical potential, } \mathrm{V}, \mathrm{MeV}\end{array}$ & 45.6 & 44.5 & 45.3 & 47.9 & 49.5 \\
\hline $\begin{array}{l}\text { Diffuseness of real part of } \\
\text { nuclear optical potential, } \\
a_{0}, F\end{array}$ & 0.65 & 0.65 & 0.65 & 0.65 & 0.65 \\
\hline $\begin{array}{l}\text { Radius constant of real part of } \\
\text { nuclear optical potential, } \\
{ }^{r_{0}}, F\end{array}$ & 1.25 & 1.25 & 1.25 & 1.25 & 1.25 \\
\hline $\begin{array}{l}\text { Strength of imaginary part of } \\
\text { nuclear optical potential, } \\
\text { W, MeV }\end{array}$ & 6.09 & 6.66 & 10.7 & 9.51 & 14. 7 \\
\hline $\begin{array}{l}\text { Diffuseness of imaginary part } \\
\text { of nuclear optical potential, } \\
a_{i}, F\end{array}$ & 0.47 & 0.47 & 0.47 & 0.47 & 0.47 \\
\hline $\begin{array}{l}\text { Radius constant of imaginary } \\
\text { part of nuclear optical } \\
\text { potential, } \mathbf{r}_{\mathbf{i}}, \mathrm{F}\end{array}$ & 1.25 & 1.25 & 1.25 & 1.25 & 1.25 \\
\hline $\begin{array}{l}\text { Strength of spin-orbit potential, } \\
\mathrm{V}_{\mathrm{so}}, \mathrm{MeV}\end{array}$ & 7.02 & 0.987 & 3.48 & 4.97 & 5.74 \\
\hline $\begin{array}{l}\text { Diffuseness of spin-orbit } \\
\text { potential, } \mathrm{a}_{\mathrm{so}}, \mathrm{F}\end{array}$ & 0.65 & 0.65 & 0.65 & 0.65 & 0.65 \\
\hline $\begin{array}{l}\text { Radius constant of spin-orbit } \\
\text { potential, } \mathrm{r}_{\text {so }}, \mathrm{F}\end{array}$ & 1.25 & 1.25 & 1.25 & 1.25 & 1.25 \\
\hline $\begin{array}{l}\text { Goodness of fit per data point, } \\
x^{2} / \mathrm{N}\end{array}$ & 5.95 & 38.4 & 8.90 & 9.52 & 8.26 \\
\hline $\begin{array}{l}\text { Goodness of fit per cross- } \\
\text { section data point, } x_{\sigma}^{2} / N_{\sigma}\end{array}$ & 1.08 & 5.21 & 6.23 & 5.32 & 6.18 \\
\hline $\begin{array}{l}\text { Goodness of fit per polarization } \\
\quad \text { data point, } x_{p}^{2} / N_{p}\end{array}$ & 18.3 & 105 & 14.8 & 16.3 & 12.2 \\
\hline Reaction cross section, $\sigma_{\mathrm{R}}, \mathrm{mb}$ & 495 & 551 & 944 & 995 & 1253 \\
\hline
\end{tabular}

${ }^{a}$ Ref. 2. 
TABLE VIII. - DIFFERENTIAL CROSS SECTIONS FOR SCATTERING OF 21-MeV

PROTONS BY TIN 116

[Incident proton energy for cross section measurements, $21.3 \mathrm{MeV}$; incident proton energy for polarization measurements, 20.8 MeV.]

\begin{tabular}{|c|c|c|c|c|c|c|c|c|c|}
\hline $\begin{array}{c}\text { Center- } \\
\text { of-mass } \\
\text { scat- } \\
\text { tering } \\
\text { angle, } \\
\theta_{\mathrm{cm}} \\
\text { deg }\end{array}$ & $\begin{array}{c}\text { Differ- } \\
\text { ential } \\
\text { cross } \\
\text { section, } \\
\mathrm{d} \sigma / \mathrm{d} \Omega \\
\mathrm{mb} / \mathrm{sr}\end{array}$ & $\begin{array}{c}\text { Statistical } \\
\text { error of } \\
\text { differen- } \\
\text { tial cross } \\
\text { section, } \\
\pm \Delta \mathrm{d} \sigma / \mathrm{d} \Omega \\
\mathrm{mb} / \mathrm{sr}\end{array}$ & $\begin{array}{l}\text { Polar- } \\
\text { ization, } \\
\text { P }\end{array}$ & $\begin{array}{c} \pm \Delta \text { Polar- } \\
\text { ization }\end{array}$ & $\begin{array}{c}\text { Center- } \\
\text { of-mass } \\
\text { scat- } \\
\text { tering } \\
\text { angle, } \\
{ }^{\theta} \mathrm{cm} \\
\text { deg }\end{array}$ & $\begin{array}{c}\text { Differ- } \\
\text { ential } \\
\text { cross } \\
\text { section, } \\
\mathrm{d} \sigma / \mathrm{d} \Omega \\
\mathrm{mb} / \mathrm{sr}\end{array}$ & $\begin{array}{c}\text { Statistical } \\
\text { error of } \\
\text { differen- } \\
\text { tial cross } \\
\text { section, } \\
\pm \Delta \mathrm{d} \sigma / \mathrm{d} \Omega \\
\mathrm{mb} / \mathrm{sr}\end{array}$ & $\begin{array}{c}\text { Polar- } \\
\text { ization, } \\
\mathbf{P}\end{array}$ & $\begin{array}{c} \pm \Delta \text { Polar }- \\
\text { ization }\end{array}$ \\
\hline 10.09 & $1.24 \times 10^{5}$ & 3. $56 \times 10^{2}$ & $\cdots$ & $\cdots$ & 90.5 & 6.64 & $5.37 \times 10^{-2}$ & 0.405 & 0.049 \\
\hline 15.13 & $2.06 \times 10^{4}$ & $5.62 \times 10^{1}$ & 0.038 & 0.025 & 95.5 & 8.50 & $1.20 \times 10^{-1}$ & -..-- & ----- \\
\hline 20.17 & $6.63 \times 10^{3}$ & 2. $53 \times 10^{1}$ & $\ldots$ & --.-- & 98.0 & -......- & $-\ldots$ & -.109 & .050 \\
\hline 22.7 & $\cdots$ & $-\ldots$ & 0 & .035 & 100.49 & 8.40 & 1. $36 \times 10^{-1}$ & --.--- & ---- \\
\hline 25.21 & $2.84 \times 10^{3}$ & 2. $37 \times 10^{1}$ & $\ldots$ & ---- & 105.48 & 6.19 & $8.66 \times 10^{-2}$ & -.309 & .048 \\
\hline 30.25 & 1. $13 \times 10^{3}$ & 6.58 & -.024 & .066 & 110.47 & 3.74 & $3.38 \times 10^{-2}$ & $-\ldots$ & $-\ldots$ \\
\hline 35.29 & $4.16 \times 10^{2}$ & 1.99 & $--\cdots$ & --- & 113.0 & $\ldots$ & - & -.677 & .067 \\
\hline 37.8 & 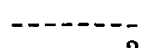 & -- & -.130 & .025 & 115.45 & 1.57 & 2. $52 \times 10^{-2}$ & ---.-- & $\ldots-$ \\
\hline 40.32 & 1. $76 \times 10^{2}$ & 1.14 & $\ldots$ & $-\cdots$ & 117.94 & 1.10 & $3.02 \times 10^{-2}$ &.---- & $-\cdots$ \\
\hline 45.35 & 8. $73 \times 10^{1}$ & $6.48 \times 10^{-1}$ & .017 & .039 & 120.43 & $8.85 \times 10^{-1}$ & $1.61 \times 10^{-2}$ & .525 & .091 \\
\hline 47.87 & 7. $26 \times 10^{1}$ & $3.80 \times 10^{-1}$ & -.... & --.-- & 122.92 & 1.04 & $2.97 \times 10^{-2}$ & -....- & $-\cdots$ \\
\hline 50.38 & 6. $70 \times 10^{1}$ & $3.56 \times 10^{-1}$ & $\ldots$ & -..- & 125.41 & 1.27 & 1. $73 \times 10^{-2}$ & -...- & --.-- \\
\hline 52.9 & $6.42 \times 10^{1}$ & 3. $59 \times 10^{-1}$ & .315 & .046 & 127.9 & $\ldots$ & $-1-2-1$ & .562 & .077 \\
\hline 55.41 & 6. $58 \times 10^{1}$ & 5. $77 \times 10^{-1}$ & $\ldots$ & -..- & 130.38 & 2.07 & $3.32 \times 10^{-2}$ & -....- & ---- \\
\hline 57.92 & $6.09 \times 10^{1}$ & 3. $50 \times 10^{-1}$ & -....- & $\ldots$ & 135.35 & 2.58 & $3.53 \times 10^{-2}$ & .228 & .071 \\
\hline 60.43 & 5. $84 \times 10^{1}$ & $5.26 \times 10^{-1}$ & -.006 & .050 & 140.32 & 2.43 & $3.79 \times 10^{-2}$ & --.--- & ----- \\
\hline 65.45 & 4. $58 \times 10^{1}$ & $4.26 \times 10^{-1}$ & -.... & -... & 142.8 & $\ldots$ & - n. & -.087 & .078 \\
\hline 68.0 & $-\cdots--$ & - & -.251 & .040 & 145.29 & 2.05 & 4. $86 \times 10^{-2}$ & ----- & ---- \\
\hline 70.47 & 2. $77 \times 10^{1}$ & $1.61 \times 10^{-1}$ & $\ldots$ & $--\ldots$ & 150.25 & 1.59 & $2.02 \times 10^{-2}$ & -.553 & .085 \\
\hline 75.48 & 1. $29 \times 10^{1}$ & $1.28 \times 10^{-1}$ & -.581 & .057 & 155.21 & 1.32 & $3.70 \times 10^{-2}$ & -...-- & ---- \\
\hline 80.49 & 5.04 & $4.20 \times 10^{-2}$ & -.... & -..-- & 157.7 & $\ldots$ & - & -.245 & .077 \\
\hline 82.99 & 4.11 & $5.84 \times 10^{-2}$ & .368 & .068 & 160.17 & 1.35 & $3.73 \times 10^{-2}$ & -.... & -... \\
\hline 85.50 & 4.29 & $4.38 \times 10^{-2}$ & $--\ldots$ & ---- & 165.13 & $\ldots$ & ------ & .352 & .081 \\
\hline 88.0 & 5.46 & $6.71 \times 10^{-2}$ & -.... & ---- & & & & & \\
\hline
\end{tabular}


TABLE IV. - DIFFERENTIAL CROSS SECTIONS FOR SCATTERING OF 21-MeV

\section{PROTONS BY NITROGEN 14}

[Incident proton energy for cross section measurements, $21.02 \mathrm{MeV}$; incident proton energy for polarization measurements, 20.8 MeV.]

\begin{tabular}{|c|c|c|c|c|c|c|c|c|c|}
\hline $\begin{array}{c}\text { Center- } \\
\text { of-mass } \\
\text { scat- } \\
\text { tering } \\
\text { angle, } \\
{ }^{\theta} \mathrm{cm} \\
\text { deg }\end{array}$ & $\begin{array}{l}\text { Differ- } \\
\text { ential } \\
\text { cross } \\
\text { section, } \\
\mathrm{d} \sigma / \mathrm{d} \Omega \text {, } \\
\mathrm{mb} / \mathrm{sr}\end{array}$ & $\begin{array}{c}\text { Statistical } \\
\text { error of } \\
\text { differen- } \\
\text { tial cross } \\
\text { section, } \\
\pm \Delta \mathrm{d \sigma} / \mathrm{d} \Omega \\
\mathrm{mb} / \mathrm{sr}\end{array}$ & $\begin{array}{c}\text { Polar- } \\
\text { ization, } \\
\text { P }\end{array}$ & $\begin{array}{c} \pm \Delta \text { Polar }- \\
\text { ization }\end{array}$ & $\begin{array}{c}\text { Center- } \\
\text { of-mass } \\
\text { scat- } \\
\text { tering } \\
\text { angle, } \\
\theta_{\mathrm{cm}} \text { ' } \\
\mathrm{deg}\end{array}$ & $\begin{array}{c}\text { Differ- } \\
\text { ential } \\
\text { cross } \\
\text { section, } \\
\mathrm{d} \sigma / \mathrm{d} \Omega \\
\mathrm{mb} / \mathrm{sr}\end{array}$ & $\begin{array}{c}\text { Statistical } \\
\text { error of } \\
\text { differen- } \\
\text { tial cross } \\
\text { section, } \\
\pm \Delta \mathrm{d} \sigma / \mathrm{d} \Omega \\
\mathrm{mb} / \mathrm{sr}\end{array}$ & $\begin{array}{l}\text { Polar- } \\
\text { ization, } \\
\text { P }\end{array}$ & $\begin{array}{c} \pm \Delta \text { Polar- } \\
\text { ization }\end{array}$ \\
\hline 5.25 & 4. $47 \times 10^{4}$ & 1. $50 \times 10^{2}$ & ------ & ---- & 83.95 & $2.82 \times 10^{1}$ & $3.19 \times 10^{-1}$ & -...- & --- \\
\hline 6.32 & 1. $84 \times 10^{4}$ & 1. $57 \times 10^{2}$ & ---- & ---- & 86.7 & $-\ldots-$ & $--1-2-1$ & 0.173 & 0.044 \\
\hline 8.46 & $5.04 \times 10^{3}$ & $2.47 \times 10^{1}$ & ---- & ---- & 88.99 & $2.16 \times 10^{1}$ & 2. $83 \times 10^{-1}$ & --- & $-\ldots$ \\
\hline 9.53 & $3.48 \times 10^{3}$ & $2.52 \times 10^{1}$ & $\ldots-\ldots$ & ---- & 94.01 & 1. $64 \times 10^{1}$ & 2. $28 \times 10^{-1}$ & $-\ldots$ & --- \\
\hline 10.6 & 2. $33 \times 10^{3}$ & 1. $43 \times 10^{1}$ & - - & $\ldots$ & 94.2 & ------ & 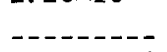 & .152 & .058 \\
\hline 11.68 & $2.00 \times 10^{3}$ & $1.40 \times 10^{1}$ & --_--- & - - & 98.99 & $1.15 \times 10^{1}$ & 1. $78 \times 10^{-1}$ & ---- & $-\ldots$ \\
\hline 12.75 & 1. $62 \times 10^{3}$ & 1. $34 \times 10^{1}$ & ---- & --- & 101.8 & ----- & $-1-1$ & -.059 & .074 \\
\hline 13.82 & 1. $40 \times 10^{3}$ & 1. $04 \times 10^{1}$ & $-\cdots$ & ---- & 103. 94 & 7.90 & 1. $61 \times 10^{-1}$ & $\ldots$ & $\ldots-\ldots$ \\
\hline 14.89 & 1. $28 \times 10^{3}$ & 8.22 & ----- & -... & 108.86 & 5.22 & $9.30 \times 10^{-2}$ & ------ & ---- \\
\hline 15.96 & 1. $16 \times 10^{3}$ & 8.27 & $-\cdots-1$ & $-\cdots$ & 109.1 & - & $-2-1-2$ & .007 & .069 \\
\hline 17.03 & $1.03 \times 10^{3}$ & 3.77 & ----- & $\ldots--$ & 113. 76 & 4.27 & $8.20 \times 10^{-2}$ & -- - & $-\ldots$ \\
\hline 19.16 & 8. $98 \times 10^{2}$ & 3.58 & $-\cdots-$ & ---- & 116.4 & ---- & - - & -.077 & .086 \\
\hline 21.3 & $7.97 \times 10^{2}$ & 5.03 & ----- & $\ldots$ & 118.62 & 3.64 & $6.49 \times 10^{-2}$ & $-\ldots-$ & $\ldots$ \\
\hline 23.43 & $6.81 \times 10^{2}$ & 3. 54 & ----- & $\ldots$ & 123.45 & 3.58 & $7.89 \times 10^{-2}$ & -_- & $\ldots$ \\
\hline 25.57 & 5. $79 \times 10^{2}$ & 4.55 & 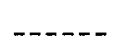 & $\ldots$ & 123.7 & $\ldots$ & - & .321 & .092 \\
\hline 27.70 & $4.80 \times 10^{2}$ & 1.76 & $-\cdots$ & ---- & 128.26 & 3.9 & $6.98 \times 10^{-2}$ & $\ldots-\ldots$ & $-\ldots$ \\
\hline 29.82 & $3.97 \times 10^{2}$ & 1.55 & ----- & $-\ldots$ & 130.8 & -... & - - & .589 & .073 \\
\hline 31.95 & 3. $22 \times 10^{2}$ & 1.52 & ----- &.--- & 133.04 & 4.09 & 5. $50 \times 10^{-2}$ & $-\ldots-$ & --- \\
\hline 37.25 & 1. $81 \times 10^{2}$ & 8. $78 \times 10^{-1}$ & $-\cdots$ & $-\ldots$ & 137.79 & 4.25 & $6.89 \times 10^{-2}$ & ---- & ---- \\
\hline 40.1 & $---1-1$ & $-\cdots-1-1$ & -0.367 & 0.028 & 138.0 & - & $-1-1-1$ & .773 & .070 \\
\hline 42.54 & $9.44 \times 10^{1}$ & $8.62 \times 10^{-1}$ & ----- & ---- & 142.53 & 4.48 & $7.66 \times 10^{-2}$ & $-\ldots-$ & $\cdots-$ \\
\hline 47.8 & 4. $54 \times 10^{1}$ & $4.21 \times 10^{-1}$ & -.464 & .043 & 145.1 & ---- & 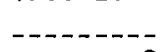 & .872 & .071 \\
\hline 53.05 & 2. $84 \times 10^{1}$ & 4. $34 \times 10^{-1}$ & $-\cdots$ & $-\ldots$ & 147.24 & 4.47 & $7.44 \times 10^{-2}$ & $-\ldots$ & --- \\
\hline 55.8 & $-\ldots . .-$ & - & -.105 & .051 & 151.94 & 4.49 & 5. $12 \times 10^{-2}$ & $-\ldots$ & ---- \\
\hline 58.27 & 2. $63 \times 10^{1}$ & 2. $58 \times 10^{-1}$ & ----- & --- & 152.2 & --- & - & .791 & .066 \\
\hline 63.46 & $3.01 \times 10^{1}$ & $2.84 \times 10^{-1}$ & --- & ---- & 156.62 & 4.34 & $7.64 \times 10^{-2}$ & $-\ldots$ & --.-- \\
\hline 63.7 & 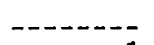 & ---1 & .187 & .057 & 159.1 & 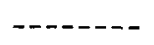 & $-\ldots-1-$ & .581 & .055 \\
\hline 68.62 & 3. $35 \times 10^{1}$ & $3.36 \times 10^{-1}$ & -...- & $-\cdots$ & 161.28 & 4.43 & $6.07 \times 10^{-2}$ & ---- & ---- \\
\hline 71.4 & $------\overline{1}$ & - & .245 & .051 & 165.94 & 4.38 & $4.81 \times 10^{-2}$ & $-\cdots-$ & ---- \\
\hline 73.76 & 3. $55 \times 10^{1}$ & 3. $84 \times 10^{-1}$ & $\ldots-\ldots$ & $-\cdots$ & 166.1 & --- & 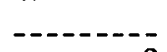 & .506 & .055 \\
\hline 78.87 & 3. $27 \times 10^{1}$ & $3.60 \times 10^{-1}$ & ---- & $-\cdots$ & 170.59 & 4.21 & $6.95 \times 10^{-2}$ & $-\cdots$ & ---- \\
\hline 79.1 & - & - - & .197 & .058 & & & & & \\
\hline
\end{tabular}


TABLE V. - DIFFERENTIAL CROSS SECTIONS FOR SCATTERING OF 21-MeV

PROTONS BY OXYGEN 16

[Incident proton energy for cross section measurements, $20.93 \mathrm{MeV}$; incident proton energy for polarization measurements $20.7 \mathrm{MeV}$.]

\begin{tabular}{|c|c|c|c|c|c|c|c|c|c|}
\hline $\begin{array}{l}\text { Center- } \\
\text { of-mass } \\
\text { scat- } \\
\text { tering } \\
\text { angle, } \\
{ }^{\theta} \mathrm{cm} \text { ' } \\
\text { deg }\end{array}$ & $\begin{array}{c}\text { Differ- } \\
\text { ential } \\
\text { cross } \\
\text { section, } \\
\mathrm{d} \sigma / \mathrm{d} \Omega \\
\mathrm{mb} / \mathrm{sr}\end{array}$ & $\begin{array}{c}\text { Statistical } \\
\text { error of } \\
\text { differen- } \\
\text { tial cross } \\
\text { section, } \\
\pm \Delta \mathrm{d} \sigma / \mathrm{d} \Omega \\
\mathrm{mb} / \mathrm{sr}\end{array}$ & $\begin{array}{l}\text { Polar- } \\
\text { ization, } \\
\text { P }\end{array}$ & $\begin{array}{c} \pm \Delta \text { Polar- } \\
\text { ization }\end{array}$ & $\begin{array}{c}\text { Center- } \\
\text { of-mass } \\
\text { scat- } \\
\text { tering } \\
\text { angle, } \\
\theta_{\mathrm{cm}} \\
\text { deg }\end{array}$ & $\begin{array}{c}\text { Differ- } \\
\text { ential } \\
\text { cross } \\
\text { section, } \\
\mathrm{d} \sigma / \mathrm{d} \Omega \\
\mathrm{mb} / \mathrm{sr}\end{array}$ & $\begin{array}{c}\text { Statistical } \\
\text { error of } \\
\text { differen- } \\
\text { tial cross } \\
\text { section, } \\
\pm \Delta \mathrm{d} \sigma / \mathrm{d} \Omega \\
\mathrm{mb} / \mathrm{sr}\end{array}$ & $\begin{array}{c}\text { Polar- } \\
\text { ization, } \\
\text { P }\end{array}$ & $\begin{array}{c} \pm \Delta \text { Polar }- \\
\text { ization }\end{array}$ \\
\hline 5.19 & $6.02 \times 10^{4}$ & 1. $18 \times 10^{2}$ & $-\cdots$ & $-\cdots$ & 68.36 & 3. $56 \times 10^{1}$ & $3.59 \times 10^{-1}$ & -..-- & -- \\
\hline 6.25 & $2.39 \times 10^{4}$ & $6.53 \times 10^{1}$ &.---1 & $-\ldots$ & 70.92 & 3. $76 \times 10^{1}$ & $4.08 \times 10^{-1}$ & -0.183 & .05 \\
\hline 8.38 & $6.55 \times 10^{3}$ & $4.04 \times 10^{1}$ & $-\cdots$ & --- & 73.48 & 3. $71 \times 10^{1}$ & $3.69 \times 10^{-1}$ & -.121 & .01 \\
\hline 10.5 & $3.00 \times 10^{3}$ & 2. $37 \times 10^{1}$ & ----- & $\ldots$ & 78.58 & 3. $59 \times 10^{1}$ & $3.47 \times 10^{-1}$ & -.371 & .054 \\
\hline 12.63 & 1. $88 \times 10^{3}$ & $1.40 \times 10^{1}$ & $\ldots \ldots$ & -..-- & 83.65 & 2. $97 \times 10^{1}$ & $3.36 \times 10^{-1}$ & $\ldots$ & $\ldots$ \\
\hline 12.84 & 1. $73 \times 10^{3}$ & 8.35 & --- & --- & 86.1 & ------ & ------ & -.307 & .043 \\
\hline 15.96 & 1. $35 \times 10^{3}$ & 7.35 & --.-- & --- & 88.69 & 2. $47 \times 10^{1}$ & $2.95 \times 10^{-1}$ & -.288 & .012 \\
\hline 17.08 & 1. $11 \times 10^{3}$ & 4.65 & $-\ldots$ & --- & 93.70 & 1. $75 \times 10^{1}$ & $2.26 \times 10^{-1}$ & -.424 & .054 \\
\hline 19.20 & $9.40 \times 10^{2}$ & 4.50 & -...- & -..- & 98.69 & 1. $21 \times 10^{1}$ & $2.12 \times 10^{-1}$ & -...- & -... \\
\hline 21.32 & $7.91 \times 10^{2}$ & 3.62 & -...- & $\ldots$ & 101.1 & --.--- & 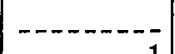 & -.502 & .074 \\
\hline 23.44 & $6.68 \times 10^{2}$ & 3.33 & $\ldots$ & $\ldots$ & 103.65 & 7.73 & 1. $67 \times 10^{-1}$ & -.452 & .021 \\
\hline 25.55 & 5. $71 \times 10^{2}$ & 3.07 & $-\ldots$ & $\ldots$ & 108.58 & 5.06 & 1. $34 \times 10^{-1}$ & -.434 & .073 \\
\hline 26.61 & 4. $69 \times 10^{2}$ & 2.22 & $\ldots$ & ---- & 113.49 & 3.31 & $1.08 \times 10^{-1}$ & - & --- \\
\hline 31.68 & $2.99 \times 10^{2}$ & 3.07 & -.-.- & -..-- & 115.8 & $\ldots$ & $----1--\bar{a}$ & -.344 & .089 \\
\hline 31.89 & $2.97 \times 10^{2}$ & 1.92 & -....- & ---- & 118.37 & 2.85 & $9.00 \times 10^{-2}$ & -.170 & .033 \\
\hline 37.16 & $1.64 \times 10^{2}$ & 1.23 & -..-- & $\ldots$ & 123.22 & 2.67 & $9.38 \times 10^{-2}$ & .062 & .089 \\
\hline 39.70 & ------ & - n..... & -0.441 & 0.031 & 128.95 & 2.78 & $8.53 \times 10^{-2}$ & --.-- & --- \\
\hline 42.41 & $7.71 \times 10^{1}$ & $6.32 \times 10^{-1}$ & .... & -.-- & 130.3 & $\ldots$ & $-\ldots$ & .344 & .081 \\
\hline 47.30 &.------ & $\ldots-\ldots-\bar{y}$ & -.531 & .041 & 132.86 & 2.76 & $9.06 \times 10^{-2}$ & .460 & .029 \\
\hline 47.43 & $3.47 \times 10^{1}$ & 5. $37 \times 10^{-1}$ & --.-- & --.-- & 137.44 & 2.61 & $3.86 \times 10^{-2}$ & .590 & .074 \\
\hline 47.64 & 3. $58 \times 10^{1}$ & $3.23 \times 10^{-1}$ & $\ldots$ & ----- & 137.65 & 2.57 & $8.43 \times 10^{-2}$ &.--- & $-\ldots$ \\
\hline 52.85 & 2. $31 \times 10^{1}$ & $2.26 \times 10^{-1}$ & $\ldots$ & $\ldots$ & 142.42 & 2.69 & $8.25 \times 10^{-2}$ & -...- & ---- \\
\hline 54.93 & $2.27 \times 10^{1}$ & $2.12 \times 10^{-1}$ & -..-- & ---- & 144.7 & $\cdots$ & $-\cdots---$ & .700 & .072 \\
\hline 55.30 & $---1--\bar{y}$ & $-\cdots-1 .-\overline{1}$ & .034 & .049 & 146.96 & 2.73 & $5.33 \times 10^{-2}$ & -..-- & $-\ldots$ \\
\hline 57.01 & 2. $45 \times 10^{1}$ & 4. $32 \times 10^{-1}$ & $\ldots$ & $-\ldots$ & 147.17 & 2.87 & $8.09 \times 10^{-2}$ & ----- & $\ldots-$ \\
\hline 58.05 & $-\cdots-1$ & $-\ldots$ & .002 & .01 & 151.90 & 3.29 & $8.67 \times 10^{-2}$ & .858 & .069 \\
\hline 60.12 & 2. $75 \times 10^{1}$ & $3.22 \times 10^{-1}$ & -...- & ---- & 156.62 & 3.87 & $8.11 \times 10^{-2}$ & ------ & ---- \\
\hline 63.10 & 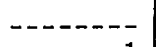 & - & .023 & .052 & 158.9 & -.-- & 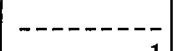 & .751 & .062 \\
\hline 63.22 & $3.09 \times 10^{1}$ & $2.89 \times 10^{-1}$ & $\ldots \ldots$ &.-- & 161.33 & 4.55 & $1.02 \times 10^{-1}$ & -.... & $\ldots$ \\
\hline 65.79 & 3. $48 \times 10^{1}$ & 4. $39 \times 10^{-1}$ & ---- & ----- & 165.82 & - & 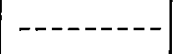 & .498 & .053 \\
\hline 68.15 & $3.39 \times 10^{1}$ & 5. $54 \times 10^{-1}$ & -...- & -... & & & & & \\
\hline
\end{tabular}


TABLE VI. - DIFFERENTIAL CROSS SECTIONS FOR SCATTERING OF 21-MeV

\section{PROTONS BY ARGON 40}

[Incident proton energy for cross section measurements, $21.13 \mathrm{MeV}$; incident proton energy for polarization measurements, 21.0 MeV.]

\begin{tabular}{|c|c|c|c|c|c|c|c|c|c|}
\hline $\begin{array}{c}\text { Center- } \\
\text { of-mass } \\
\text { scat- } \\
\text { tering } \\
\text { angle, } \\
\theta_{\mathrm{cm}} \text { ' } \\
\text { deg }\end{array}$ & $\begin{array}{c}\text { Differ- } \\
\text { ential } \\
\text { cross } \\
\text { section, } \\
\text { d } / \mathrm{d} \Omega \\
\mathrm{mb} / \mathrm{sr}\end{array}$ & $\begin{array}{c}\text { Statistical } \\
\text { error of } \\
\text { differen- } \\
\text { tial cross } \\
\text { section, } \\
\pm \Delta \mathrm{d} \sigma / \mathrm{d} \Omega \\
\mathrm{mb} / \mathrm{sr}\end{array}$ & $\begin{array}{c}\text { Polar- } \\
\text { ization, } \\
\text { P }\end{array}$ & $\begin{array}{l} \pm \Delta \text { Polar- } \\
\text { ization }\end{array}$ & $\begin{array}{c}\text { Center- } \\
\text { of-mass } \\
\text { scat- } \\
\text { tering } \\
\text { angle, } \\
{ }^{\circ} \mathrm{cm} \text { ' } \\
\text { deg }\end{array}$ & $\begin{array}{c}\text { Differ- } \\
\text { ential } \\
\text { cross } \\
\text { section, } \\
\mathrm{d} \sigma / \mathrm{d} \Omega \\
\mathrm{mb} / \mathrm{sr}\end{array}$ & $\begin{array}{c}\text { Statistical } \\
\text { error of } \\
\text { differen- } \\
\text { tial cross } \\
\text { section, } \\
\pm \Delta \mathrm{d \sigma} / \mathrm{d} \Omega \\
\mathrm{mb} / \mathrm{sr}\end{array}$ & $\begin{array}{c}\text { Polar- } \\
\text { ization, } \\
\text { P }\end{array}$ & $\begin{array}{c} \pm \Delta \text { Polar } \\
\text { ization }\end{array}$ \\
\hline 5.0 & $3.22 \times 10^{5}$ & $9.42 \times 10^{2}$ & --.-- & ---- & 76.40 & - & --------- & 0.225 & 0.158 \\
\hline 6.02 & 1. $30 \times 10^{5}$ & $5.50 \times 10^{2}$ & -...- & $\ldots$ & 81.29 & $6.72 \times 10^{1}$ & 1. $64 \times 10^{-1}$ & -...- & $\ldots$ \\
\hline 8.07 & $3.28 \times 10^{4}$ & 2. $50 \times 10^{2}$ & 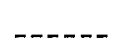 & --- & 83.90 & 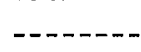 & ------- & .285 & .124 \\
\hline 10.12 & $1.15 \times 10^{4}$ & 1. $15 \times 10^{2}$ & --- & ---- & 86.31 & 9.60 & $2.23 \times 10^{-1}$ & $-\cdots-$ & $-\ldots$ \\
\hline 12.17 & $5.79 \times 10^{3}$ & 2. $35 \times 10^{1}$ & ---- & ---- & 91.32 & $1.09 \times 10^{1}$ & 2. $53 \times 10^{-1}$ & .326 & .123 \\
\hline 14.22 & 3. $36 \times 10^{3}$ & 1. $21 \times 10^{1}$ & ---- & --.-- & 96.31 & $1.06 \times 10^{1}$ & $2.35 \times 10^{-1}$ & $-\cdots-$ & --- \\
\hline 16.27 & 2. $17 \times 10^{3}$ & 8.04 & ----- & ---- & 98.90 & $-\ldots--$ & $-\cdots-$ & -.050 & .138 \\
\hline 18.32 & 1. $53 \times 10^{3}$ & $1.07 \times 10^{1}$ & $-\cdots$ & ---- & 101.29 & 8.83 & 2. $73 \times 10^{-1}$ & ---- & $-\cdots$ \\
\hline 20.37 & 1. $06 \times 10^{3}$ & 6.33 & ----- & -..- & 106.27 & 6.64 & $1.93 \times 10^{-1}$ & ---- & --- \\
\hline 22.41 & $7.46 \times 10^{2}$ & 3.83 & --.--- & ----- & 106.4 & $\ldots$ & $-\cdots$ & -.066 & .072 \\
\hline 24.46 & $5.14 \times 10^{2}$ & 3.07 & - - - & --- & 111.23 & 3.83 & $1.21 \times 10^{-1}$ & $-\ldots-$ & $\ldots$ \\
\hline 26.51 & 3. $49 \times 10^{2}$ & 2.20 & $-\ldots$ & ---- & 113.8 & $-\cdots$ & $-1-1-1$ & -.040 & .077 \\
\hline 28.55 & $2.29 \times 10^{2}$ & 1.91 & $-\ldots$ & -- - & 116.18 & 2.47 & 7. $72 \times 10^{-2}$ & ---- & $\ldots-$ \\
\hline 30.60 & 1. $46 \times 10^{2}$ & $9.73 \times 10^{-1}$ & $-\ldots--$ & ---- & 121.12 & 1.53 & 7. $11 \times 10^{-2}$ & .482 & .098 \\
\hline 35.70 & 1. $55 \times 10^{1}$ & 2. $71 \times 10^{-1}$ & -....- & $-\ldots$ & 126.05 & 1.05 & 4. $70 \times 10^{-2}$ & ---- & $\ldots$ \\
\hline 38.40 & - & - & 0.754 & 0.099 & 128.6 & ----- & $--n-1$ & .852 & .101 \\
\hline 40.80 & $3.64 \times 10^{1}$ & $3.96 \times 10^{-1}$ & $-\ldots$ & $\ldots$ & 130.98 & 1.02 & $5.08 \times 10^{-2}$ & $-\ldots-$ & ---- \\
\hline 45.89 & $7.03 \times 10^{1}$ & 7. $21 \times 10^{-1}$ & $-\ldots$ & $\ldots$ & 135.89 & 1.39 & 4. $82 \times 10^{-2}$ & .405 & .129 \\
\hline 46.0 & - & - & .260 & .085 & 140.8 & 1.72 & 5. $65 \times 10^{-2}$ & ---- & ---- \\
\hline 50.98 & 8. $28 \times 10^{1}$ & $6.88 \times 10^{-1}$ & ---- & --- & 143.4 & $-\ldots$ & - - - & .280 & .072 \\
\hline 53.60 & $---1--$ & -----1 & -.209 & .092 & 150.59 & 2.05 & 5. $56 \times 10^{-2}$ & -.057 & .105 \\
\hline 56.06 & 7. $11 \times 10^{1}$ & $7.03 \times 10^{-1}$ & 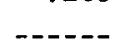 &.--- & 155.48 & 1.61 & 5. $35 \times 10^{-2}$ & --- & $-\ldots$ \\
\hline 61.12 & $4.65 \times 10^{1}$ & 4. $84 \times 10^{-1}$ & -.494 & .066 & 158.1 & ---- & - & .716 & .089 \\
\hline 66.18 & 2. $31 \times 10^{1}$ & $3.21 \times 10^{-1}$ & ---- & $-\ldots$ & 160.36 & 1.19 & 4. $23 \times 10^{-2}$ &.---- & --- \\
\hline 68.8 & $-\cdots-$ & - - & -.467 & .112 & 165.24 & .88 & 2. $15 \times 10^{-2}$ & -..-- & -... \\
\hline 71.23 & $1.02 \times 10^{1}$ & $2.03 \times 10^{-1}$ & --- & ---- & 165.4 & $-\ldots$ & - - & .488 & .108 \\
\hline 76.27 & 5.87 & $1.81 \times 10^{-1}$ & ------ & ---- & & & & & \\
\hline
\end{tabular}


TABLE VII. - DIFFERENTIAL CROSS SECTIONS FOR SCATTERING OF 21-MeV

PROTONS BY NICKEL 58

[Incident proton energy for cross section measurements, $21.3 \mathrm{MeV}$; incident proton energy for polarization measurements, 20.9 MeV.]

\begin{tabular}{|c|c|c|c|c|c|c|c|c|c|}
\hline $\begin{array}{l}\text { Center- } \\
\text { of-mass } \\
\text { scat- } \\
\text { tering } \\
\text { angle, } \\
\theta_{\text {cm' }} \\
\text { deg }\end{array}$ & $\begin{array}{c}\text { Differ- } \\
\text { ential } \\
\text { cross } \\
\text { section, } \\
\mathrm{d} \sigma / \mathrm{d} \Omega \\
\mathrm{mb} / \mathrm{sr}\end{array}$ & $\begin{array}{l}\text { Statistical } \\
\text { error of } \\
\text { differen- } \\
\text { tial cross } \\
\text { section, } \\
\pm \Delta d \sigma / \mathrm{d} \Omega \\
\mathrm{mb} / \mathrm{sr}\end{array}$ & $\begin{array}{l}\text { Polar- } \\
\text { ization, } \\
\text { P }\end{array}$ & $\begin{array}{l} \pm \Delta \text { Polar }- \\
\text { ization }\end{array}$ & $\begin{array}{l}\text { Center- } \\
\text { of-mass } \\
\text { scat- } \\
\text { tering } \\
\text { angle, } \\
\theta_{\mathrm{cm}}, \\
\text { deg }\end{array}$ & $\begin{array}{c}\text { Differ- } \\
\text { ential } \\
\text { cross } \\
\text { section, } \\
\mathrm{d} \sigma / \mathrm{d} \Omega \\
\mathrm{mb} / \mathrm{sr}\end{array}$ & $\begin{array}{c}\text { Statistical } \\
\text { error of } \\
\text { differen- } \\
\text { tial cross } \\
\text { section, } \\
\pm \Delta \mathrm{d} \sigma / \mathrm{d} \Omega \\
\mathrm{mb} / \mathrm{sr}\end{array}$ & $\begin{array}{c}\text { Polar- } \\
\text { ization, } \\
\mathbf{P}\end{array}$ & $\begin{array}{l} \pm \Delta \text { Polar }- \\
\text { ization }\end{array}$ \\
\hline 10.17 & $3.68 \times 10^{4}$ & $7.37 \times 10^{1}$ & $--\cdots--$ & ----- & 85.99 & $1.90 \times 10^{1}$ & $9.14 \times 10^{-2}$ & ----- & ---- \\
\hline 15.26 & $5.03 \times 10^{3}$ & 9.51 & -0.017 & 0.009 & 91.00 & 1. $51 \times 10^{1}$ & $6.10 \times 10^{-2}$ & -0.215 & 0.044 \\
\hline 20.34 & 1. $50 \times 10^{3}$ & 4.72 & $-\ldots$ & $-\cdots--$ & 95.99 & 9.30 & $6.78 \times 10^{-2}$ & ------ & $-\ldots-$ \\
\hline 22.9 & $------\overline{0}$ & - - n..... & -.110 & .021 & 98.5 & ------ & $-------\bar{n}$ & -.597 & .067 \\
\hline 25.42 & $5.41 \times 10^{2}$ & 2.54 & ----- & ---- & 100.98 & 4.80 & $4.67 \times 10^{-2}$ & ------ & ---- \\
\hline 30.5 & 1. $99 \times 10^{2}$ & 1.22 & .096 & .045 & 105.96 & 2.59 & $3.27 \times 10^{-2}$ & -.297 & .069 \\
\hline 35.57 & 1. $22 \times 10^{2}$ & $7.30 \times 10^{-1}$ & ----- & --- & 107.95 & 2.37 & $3.06 \times 10^{-2}$ & ---- & $-\ldots$ \\
\hline 36.59 & $1.18 \times 10^{2}$ & 5. $62 \times 10^{-1}$ & $-\cdots---$ & $\ldots \ldots$ & 110.94 & 2.66 & $3.51 \times 10^{-2}$ & $\ldots-\cdots$ & $-\ldots$ \\
\hline 38.1 & $-\cdots-1$ & $---\cdots--\overline{1}$ & .186 & .039 & 113.4 & $-\ldots-\ldots$ & $--1-1--$ & .600 & .065 \\
\hline 38.61 & $1.18 \times 10^{2}$ & $7.35 \times 10^{-1}$ & ---- & ---- & 115.9 & 3.62 & 4. $75 \times 10^{-2}$ & 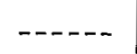 & ---- \\
\hline 40.64 & $1.21 \times 10^{2}$ & 8. $34 \times 10^{-1}$ & ----- & ---- & 120.86 & 4.25 & 4. $06 \times 10^{-2}$ & .592 & .064 \\
\hline 45.70 & $1.19 \times 10^{2}$ & $6.78 \times 10^{-1}$ & -.091 & .037 & 125.82 & 4.49 & $6.19 \times 10^{-2}$ & $\ldots \ldots$ & $-\ldots-$ \\
\hline 50.76 & $8.98 \times 10^{1}$ & $3.49 \times 10^{-1}$ & ----- & --- & 128.3 & ------ & $-\cdots----\frac{0}{0}$ & .569 & .071 \\
\hline 53.3 & $-------\overline{1}$ & $-\cdots----$ & -.347 & .050 & 130.76 & 4.19 & 5. $49 \times 10^{-2}$ & ------ & ----- \\
\hline 55.82 & $5.23 \times 10^{1}$ & $5.27 \times 10^{-1}$ & ------ & $-\ldots-$ & 135.70 & 3.67 & $5.36 \times 10^{-2}$ & .008 & .075 \\
\hline 60.86 & $2.08 \times 10^{1}$ & 1. $12 \times 10^{-1}$ & -.735 & .058 & 140.64 & 3.43 & $2.95 \times 10^{-2}$ & $-\cdots-$ & ---- \\
\hline 64.90 & 7.24 & $6.39 \times 10^{-2}$ & $\ldots-\cdots$ & $\ldots-$ & 143.1 & $\ldots \ldots$ & $--------\frac{-}{n}$ & -.371 & .083 \\
\hline 65.90 & 5.58 & $5.64 \times 10^{-2}$ & ----- & $-\cdots$ & 145.57 & 3.30 & 4. $29 \times 10^{-2}$ & ----- & ---- \\
\hline 66.91 & 4.62 & 4. $54 \times 10^{-2}$ & ------ & ---- & 150.50 & 3.44 & 4. $47 \times 10^{-2}$ & -.130 & .079 \\
\hline 68.92 & 4.17 & 4. $17 \times 10^{-2}$ & .115 & .077 & 155.42 & 3.48 & $4.39 \times 10^{-2}$ & ----- & ---- \\
\hline 70.94 & 5.50 & 3. $30 \times 10^{-2}$ & ----- & $\ldots-$ & 157.9 & 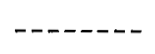 & $-\cdots----\overline{0}$ & .327 & .075 \\
\hline 75.96 & 1. $22 \times 10^{1}$ & 1. $15 \times 10^{-1}$ & .389 & .055 & 160.34 & 3.20 & $4.23 \times 10^{-2}$ & ------ & ---- \\
\hline 80.98 & 1. $89 \times 10^{1}$ & 1. $36 \times 10^{-1}$ & ----- & $-\cdots$ & 165.26 & $---n--$ & --------- & .592 & .077 \\
\hline 83.4 & $-\ldots-\ldots$ & $------\cdots$ & .092 & .037 & & & & & \\
\hline
\end{tabular}




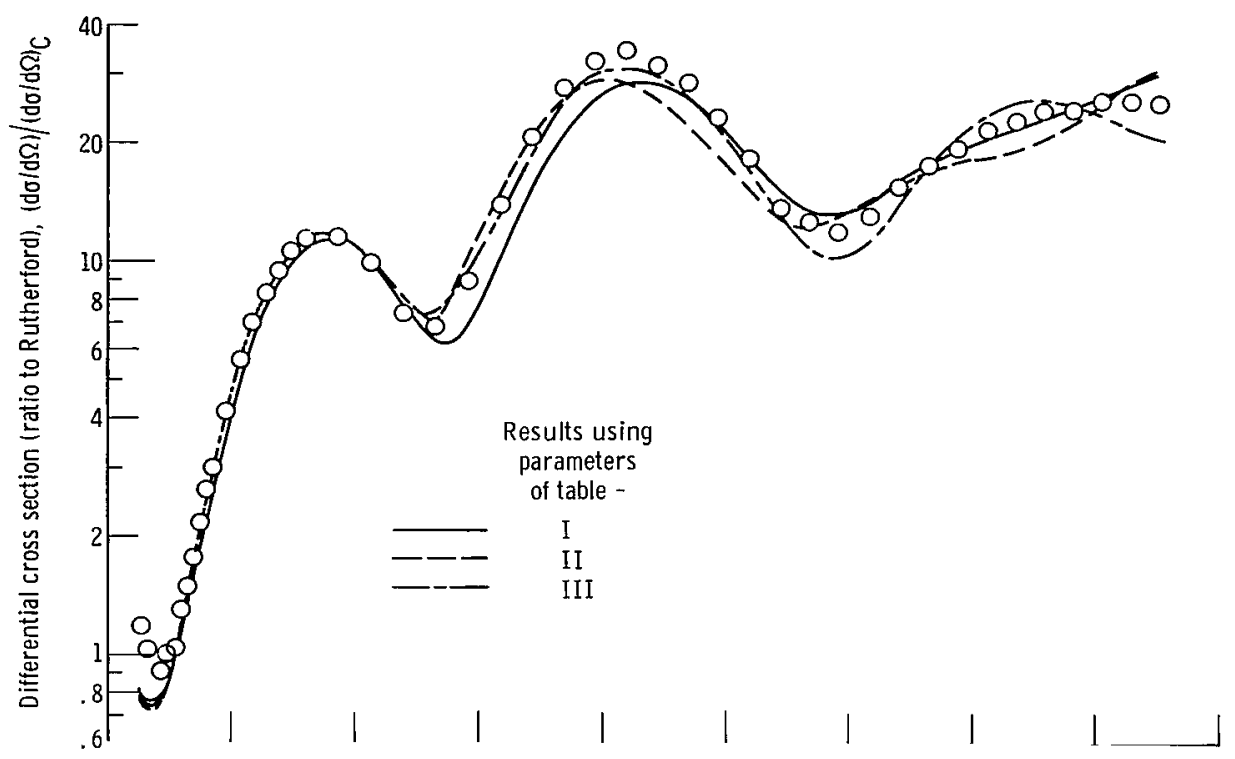

(a) Elastic cross sections. Incident proton energy, $21.02 \mathrm{MeV}$.

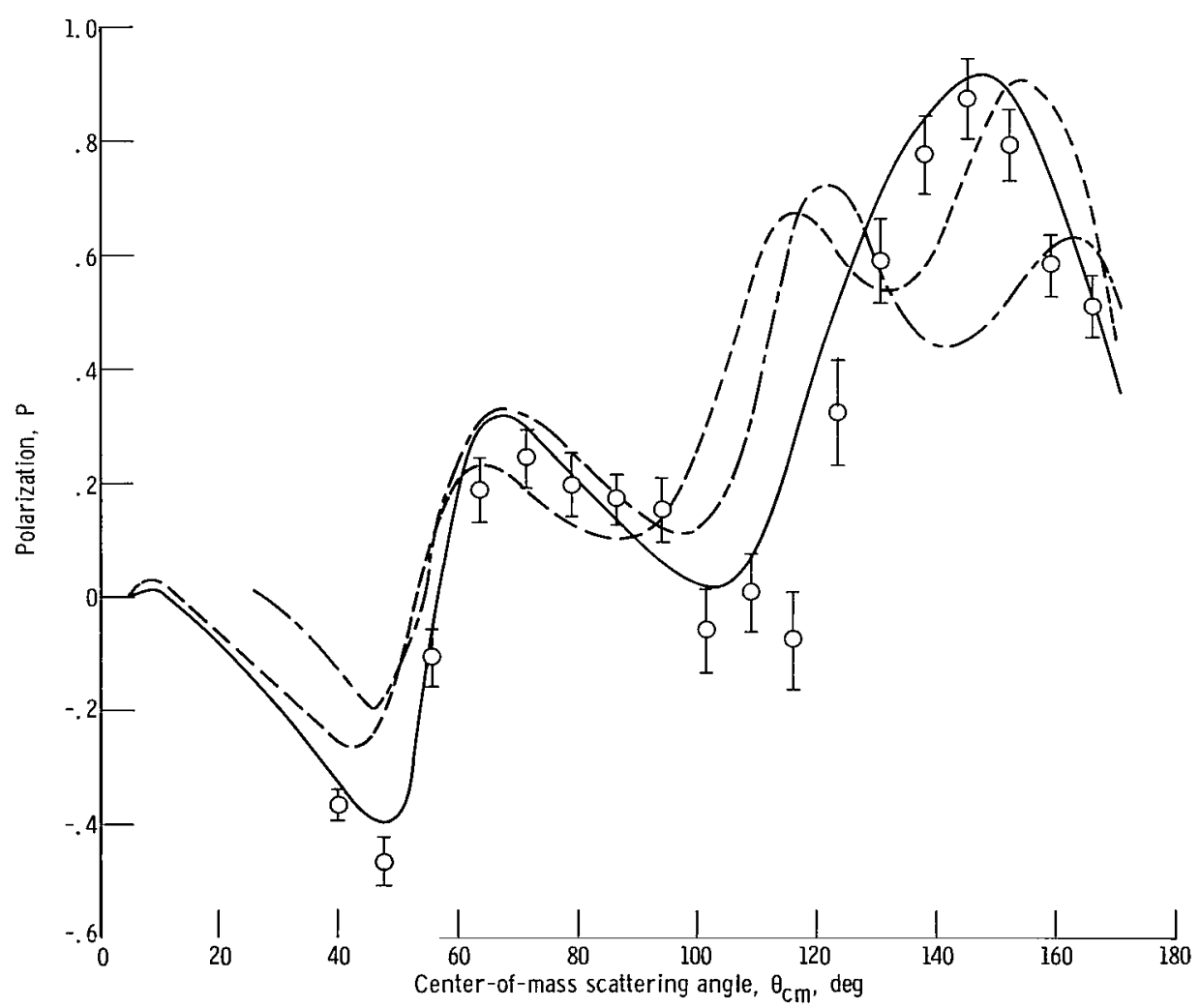

(b) Elastic polarizations. Incident proton energy, $20.8 \mathrm{MeV}$.

Figure 1. - Experimental and theoretical cross sections and polarizations for elastic scattering from nitrogen 14 of $21-\mathrm{MeV}$ protons. 


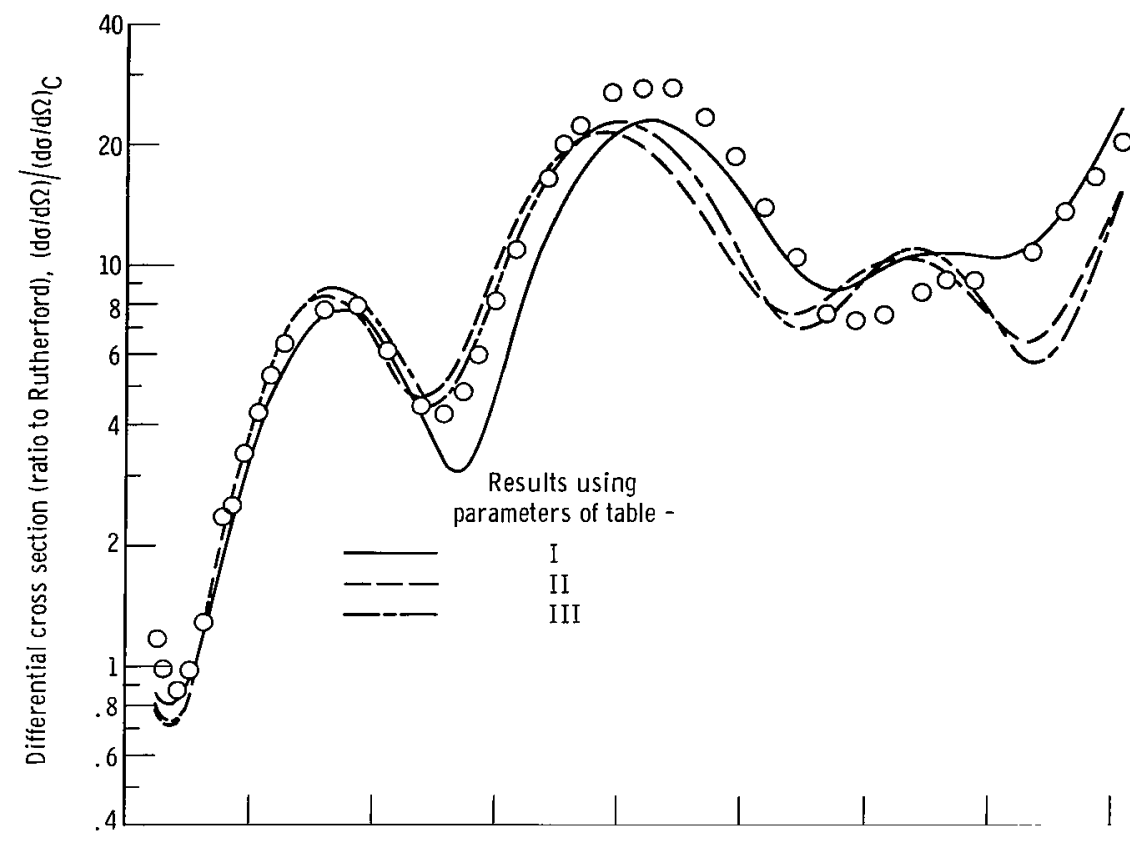

(a) Cross sections. Incident proton energy, $20.93 \mathrm{MeV}$.

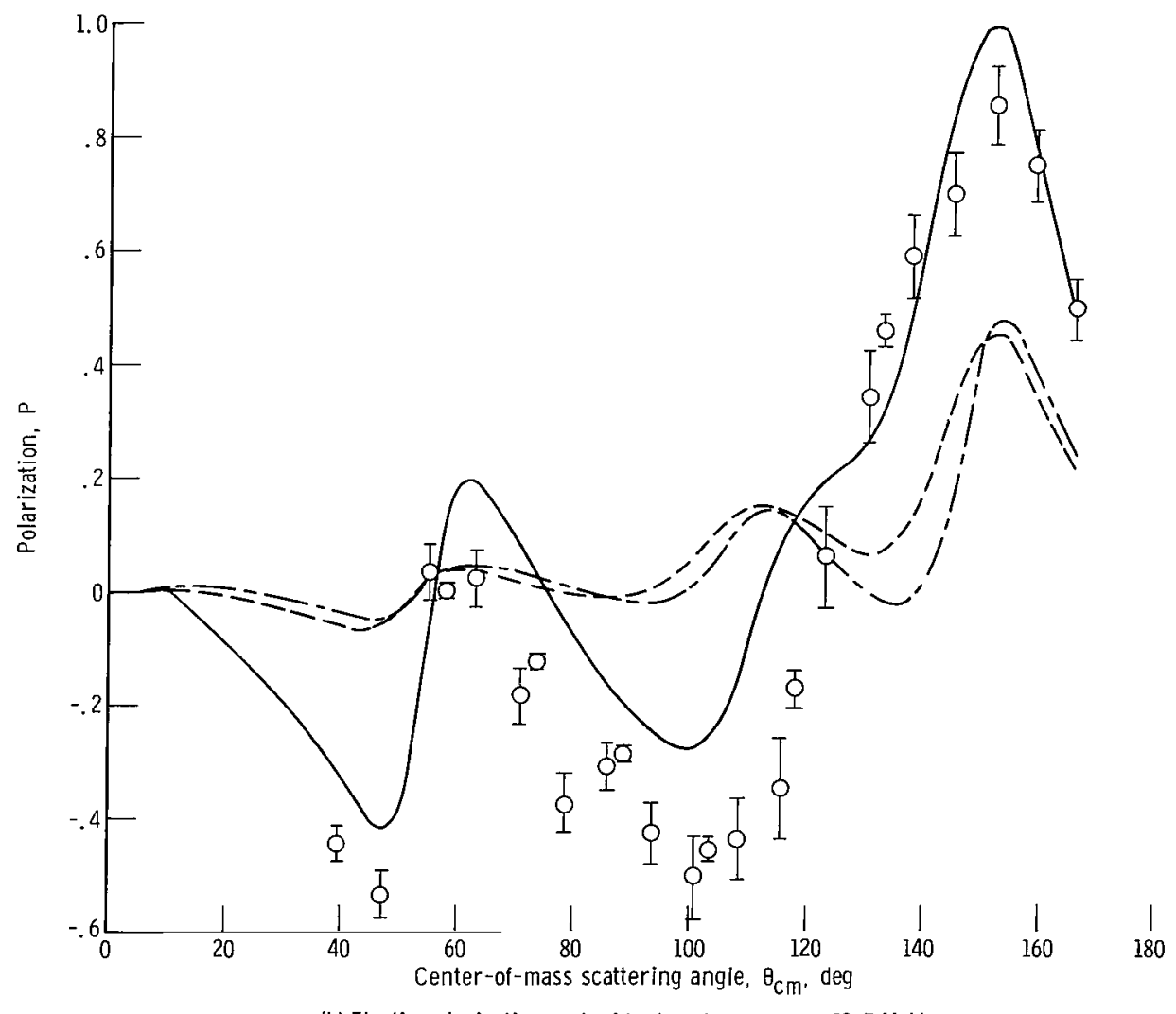

(b) Elastic polarizations. Incident proton energy, $20.7 \mathrm{MeV}$.

Figure 2. - Experimental and theoretical cross sections and polarizations for elastic scattering from oxygen 16 of $21-\mathrm{MeV}$ protons. 


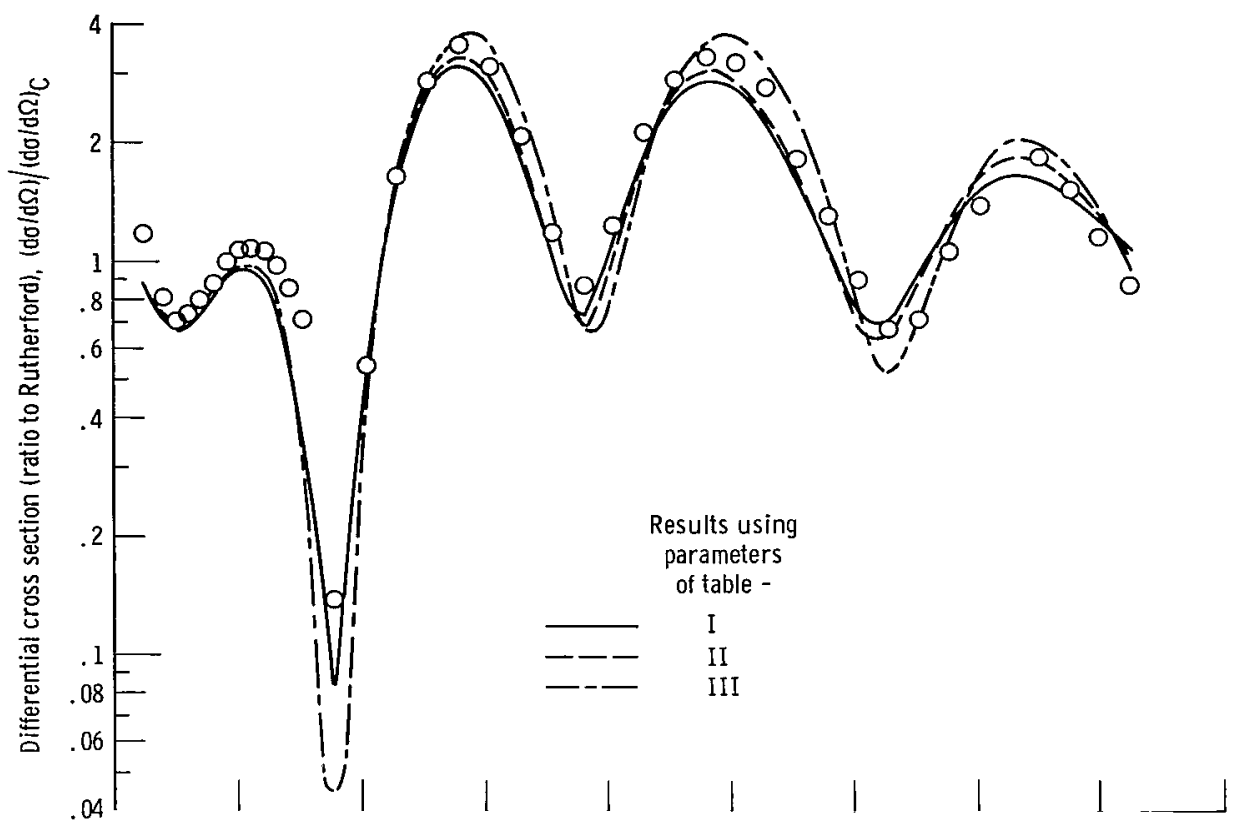

(a) Cross-sections. Incident proton energy, 21. $13 \mathrm{MeV}$.

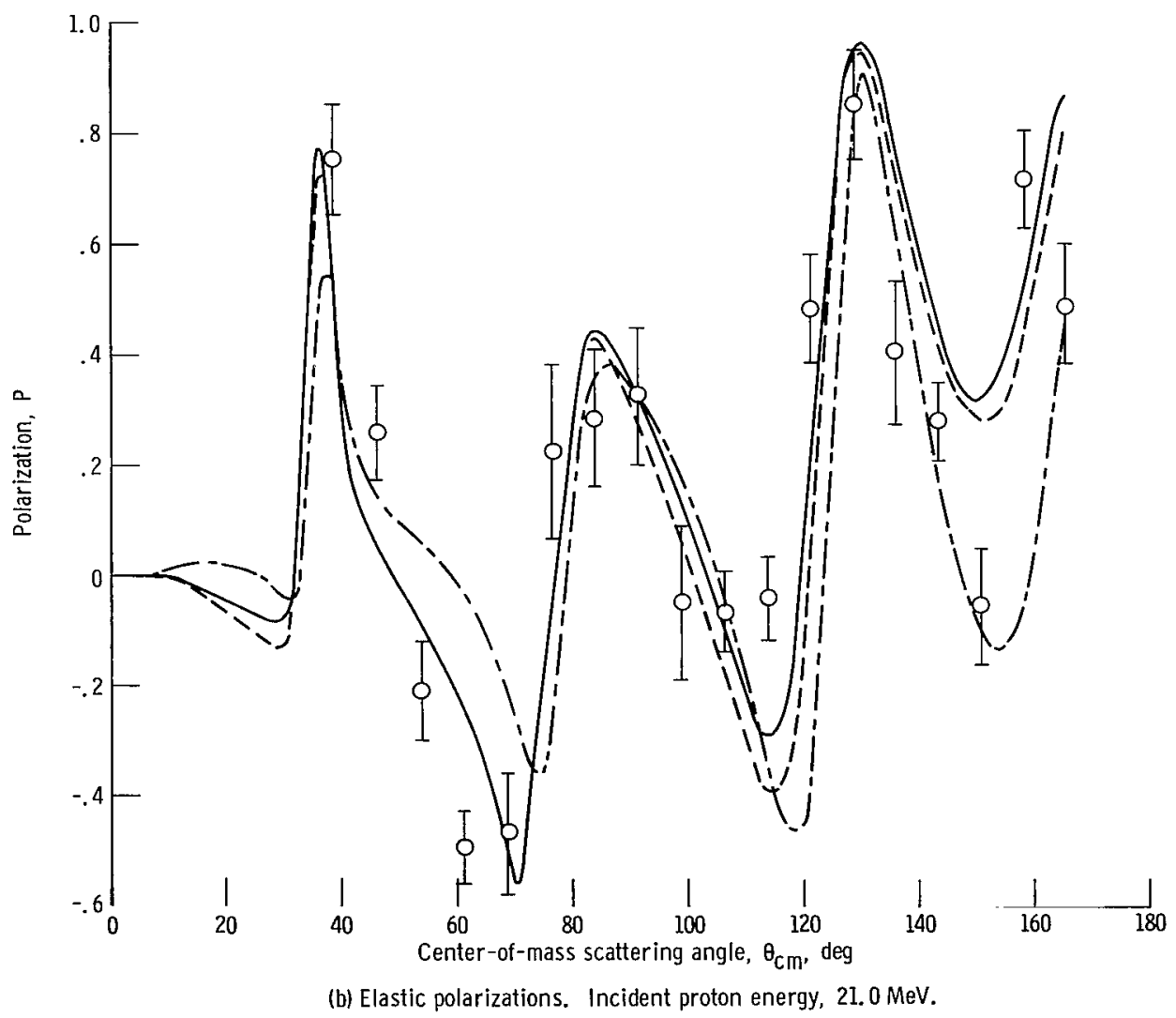

Figure 3. - Experimental and theoretical cross sections and polarizations for elastic scattering from argon 40 of $21-\mathrm{MeV}$ protons. 


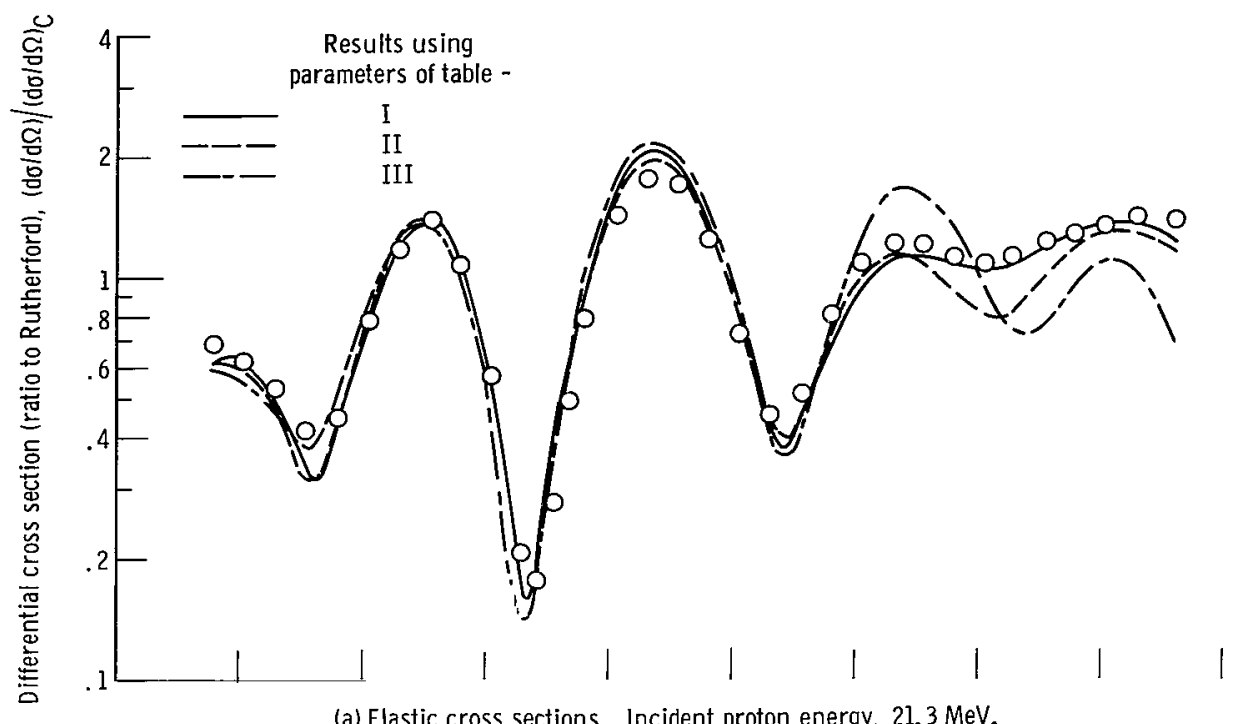

(a) Elastic cross sections. Incident proton energy, 21.3 MeV.

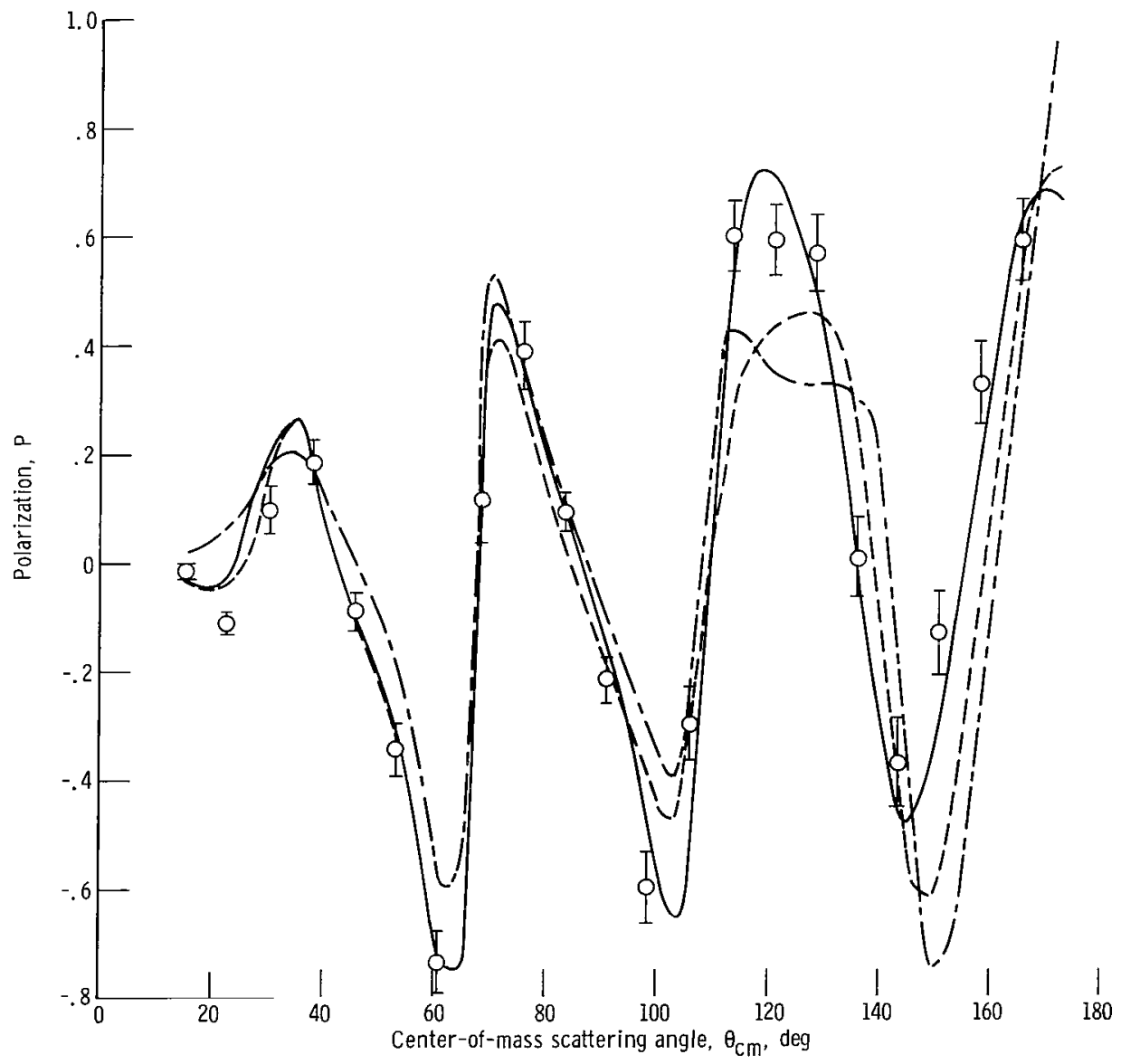

(b) Elastic polarizations. Incident proton energy, $20.9 \mathrm{MeV}$.

Figure 4. - Experimental and theoretical cross sections and polarizations for elastic scattering from nickel 58 of $21-\mathrm{MeV}$ protons. 


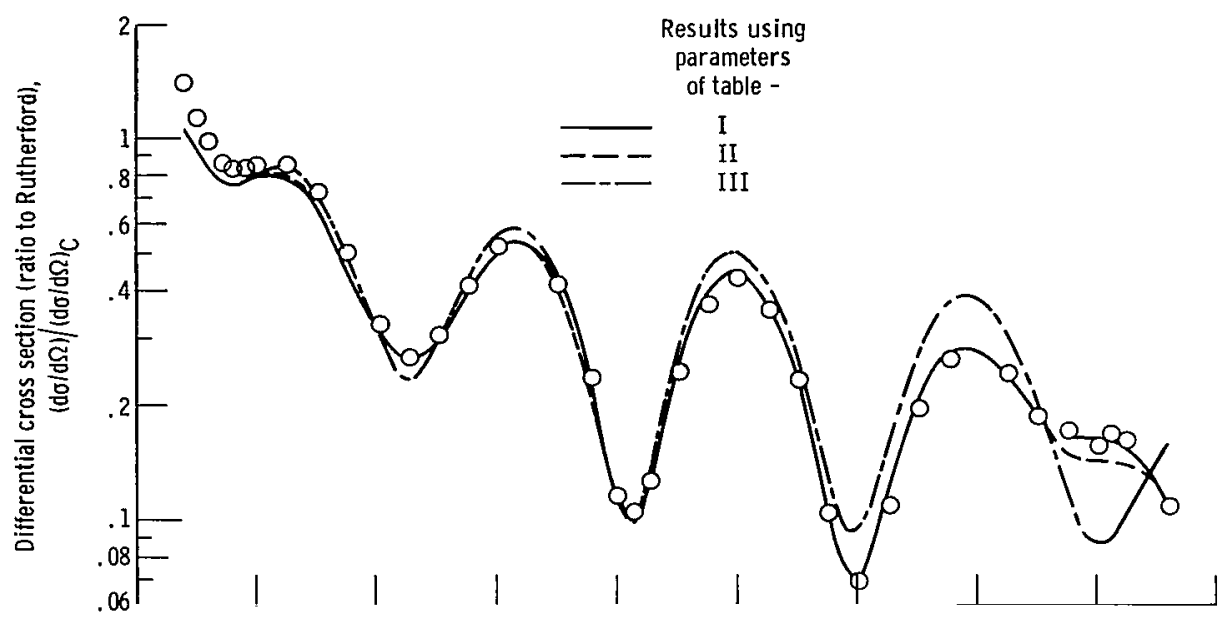

(a) Elastic cross sections. Incident proton energy, $21.3 \mathrm{MeV}$.

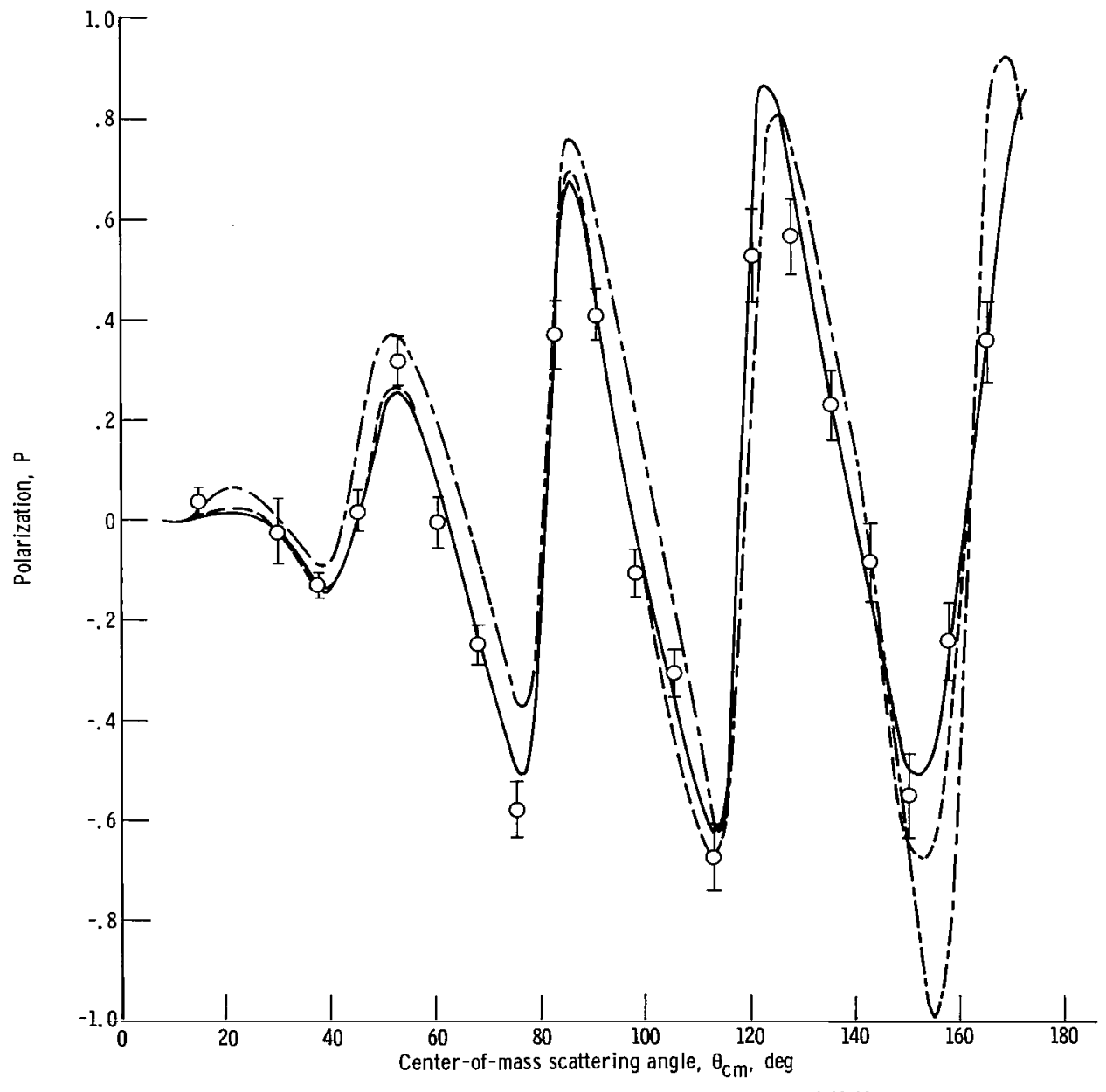

(b) Elastic polarizations. Incident proton energy, $20.8 \mathrm{MeV}$.

Figure 5. - Experimental and theoretical cross sections and polarizations for elastic scattering from tin 116 of 2l-MeV protons. 


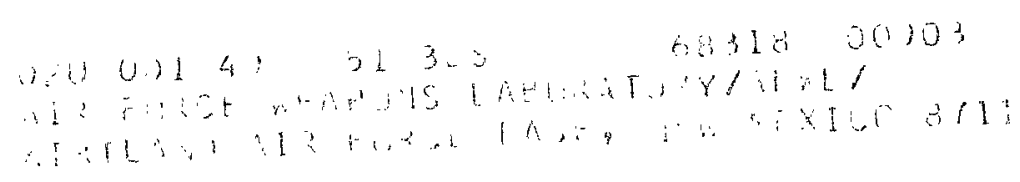

POSTMASTER: If Undeliverable (Section 1

"The aeronatitical and space activities of the United States shall be conducted so as to contribute . . to the expansion of buman knowledge of phenomena in the atmosphere and space. The Administration shall provide for the widest practicable and appropriate dissemination of information concerning its activities and the results thereof."

- National Aeronautics And Space ACt of 1958

\section{NASA SCIENTIFIC AND TECHNICAL PUBLICATIONS}

TECHNICAL REPORTS: Scientific and technical information considered important, complete, and a lasting contribution to existing knowledge.

TECHNICAL NOTES: Information less broad in scope but nevertheless of importance as a contribution to existing knowledge.

\section{TECHNICAL MEMORANDUMS:}

Information receiving limited distribution because of preliminary data, security classification, or other reasons.

CONTRACTOR REPORTS: Scientific and technical information generated under a NASA contract or grant and considered an important contribution to existing knowledge.
TECHNICAL TRANSLATIONS: Information published in a foreign language considered to merit NASA distribution in English.

SPECIAL PUBLICATIONS: Information derived from or of value to NASA activities. Publications include conference proceedings, monographs, data compilations, handbooks, sourcebooks, and special bibliographies.

TECHNOLOGY UTILIZATION PUBLICATIONS: Information on technology used by NASA that may be of particular interest in commercial and other non-aerospace applications. Publications include Tech Briefs, Technology Utilization Reports and Notes, and Technology Surveys.

Details on the availability of these publications may be obtained from:

SCIENTIFIC AND TECHNICAL INFORMATION DIVISION

NATIONAL AERONAUTICS AND SPACE ADMINISTRATION

Washington, D.C. 20546 